\title{
Synthesis and Antimicrobial Evaluation of Amphiphilic Neamine Derivatives
}

\author{
Isabelle Baussanne, ${ }^{\dagger}$ Antoine Bussière, ${ }^{\dagger}$ Somnath Halder, ${ }^{\dagger}$ Carine Ganem-Elbaz, ${ }^{\star}$ Myriam Ouberai, ${ }^{\S}$ Mickael Riou, ${ }^{\S}$ \\ Jean-Marc Paris, * Eric Ennifar," Marie-Paule Mingeot-Leclercq, ${ }^{\S}$ and Jean-Luc Décout*,† \\ ${ }^{\dagger}$ Université de Grenoble I/CNRS, UMR 5063, Département de Pharmacochimie Moléculaire, ICMG FR 2607, France, ${ }^{\star}$ Ecole Nationale \\ Supérieure de Paris/CNRS, UMR 7573, France, ${ }^{\S}$ Université Catholique de Louvain, Louvain Drug Research Institute, LDRI, Unité de \\ Pharmacologie Cellulaire et Moléculaire, FACM, Brussels, Belgium, and "Université de Strasbourg/CNRS, Institut de Biologie Moléculaire \\ et Cellulaire, Architecture et Réactivité de l'ARN, France
}

Received May 28, 2009

\begin{abstract}
The aminoglycoside antibiotics bind to the $16 \mathrm{~S}$ bacterial rRNA and disturb the protein synthesis. One to four hydroxyl functions of the small aminoglycoside neamine were capped with phenyl, naphthyl, pyridyl, or quinolyl rings. The $3^{\prime}, 4^{\prime}-(\mathbf{6}), 3^{\prime}, 6-(\mathbf{7 a})$, and the $3^{\prime}, 4^{\prime}, 6-(\mathbf{1 0 a}) 2$-naphthylmethylene derivatives appeared to be active against sensitive and resistant Staphylococcus aureus strains. 10a also showed marked antibacterial activities against Gram (-) bacteria, including strains expressing enzymes modifying aminoglycosides, efflux pumps, or rRNA methylases. 7a and 10a revealed a weak and aspecific binding to a model bacterial 16S rRNA. Moreover, as compared to neomycin B, 10a showed a lower ability to decrease ${ }^{3} \mathrm{H}$ leucine incorporation into proteins in Pseudomonas aeruginosa. All together, our results suggest that the $3^{\prime}, 4^{\prime}, 6$-tri-2-naphthylmethylene neamine derivative 10a should act against Gram (-) bacteria through a mechanism different from inhibition of protein synthesis, probably by membrane destabilization.
\end{abstract}

\section{Introduction}

Ribosomal RNA (rRNA) is the main target of clinically important antibiotics such as the natural drugs aminoglycosides. These antibacterial agents are active against both Gram (-) and Gram (+) pathogens and continue to play an important role to treat serious infections, usually in combination with $\beta$-lactams. ${ }^{1}$ The aminoglycosides are pseudooligosaccharides, which carry generally four to six amine functions positively charged at $\mathrm{pH}$ 7. They bind to the A-site of the 16S bacterial rRNA, cause mRNA decoding errors, block mRNA and tRNA translocation, and inhibit ribosome recycling. ${ }^{2}$ Neomycin B is one of the most studied aminoglycosides. ${ }^{1,2}$ As observed with other aminoglycosides, a high level of resistance to neomycin B that involves enzymatic modifications of the hydroxyl and amine functions has emerged. ${ }^{3}$ Moreover, since 2003, methylation of 16S rRNA appeared to be a serious threat to the aminoglycoside antibiotics through the action of plasmid-mediated methyltransferases. ${ }^{4}$ These enzymes are spreading to different species and are found to confer high levels of resistance to clinically useful aminoglycosides like amikacin, tobramycin, and gentamicin. Methylation of specific nucleotides within the A-site of rRNA hampers binding of aminoglycosides.

In the search for new antibiotic agents, neamine 1 (Figure 1) incorporating two rings of neomycin $\mathrm{B}$ has appeared to be the minimum scaffold necessary for binding to $16 \mathrm{~S} \mathrm{rRNA}^{5}$ as well as an attractive starting molecule. ${ }^{6}$ Earlier, neamine derivatives have been prepared through modifications of the amino

*To whom correspondence should be addressed. Phone: +33476635317. Fax: +33476635298. E-mail: Jean-Luc.Decout@ujf-grenoble.fr. groups or the 3'-, 5-, or 6-hydroxyl functions in order to increase the affinity for rRNA and prevent the activity of aminoglycoside-modifying enzymes. ${ }^{6}$

To further improve the activity of neamine derivatives and protect them from enzymatic modifications, we introduced aromatic rings from the hydroxyl functions of neamine through reactions with arylmethylene bromides. These modifications, leading to more lipophilic compounds than neamine, should increase the affinity and the specificity for different RNA targets through groove binding and/or stacking. In this approach, the naphthyl ring appeared attractive. Indeed, the affinity of polyamines consisting of ethylenediamine units equipped with either one or two naphthyl, anthryl, or acridyl units toward polyA.polyU, as a RNA model, and poly(dA).poly(dT), as a DNA model, has been reported. ${ }^{7}$ A higher selectivity for binding to RNA in comparison to DNA has been observed with naphthyl derivatives, the larger aromatic units preferring binding to DNA. This difference was explained through a preference for groove binding of the naphthyl rings and for intercalation in DNA of the larger aromatic rings.

To establish the rational basis of structure/activity relationships, we synthesized sixteen mono-, di-, tri-, and tetraarylmethylene neamine derivatives and determined their antibacterial activity on Gram (+) and Gram (-) bacteria, sensitive, and resistant strains.

\section{Results}

Chemistry. Previously, we have reported a route for preparing $4^{\prime}-, 5$-, and $4^{\prime}, 5$-neamine derivatives using trityl (Tr) and $p$-methoxybenzyl (PMB) groups for protecting the amine and hydroxyl functions, respectively. ${ }^{8}$ 


\begin{tabular}{|c|c|}
\hline $\begin{array}{l}\text { 1: neamine, } \mathrm{R}^{1}=\mathrm{R}^{2}=\mathrm{R}^{3}=\mathrm{R}^{4}=\mathrm{H} \\
\text { 2: } 3^{\prime}-2 \mathrm{NM}, \mathrm{R}^{1}=\mathrm{R}^{3}=\mathrm{R}^{4}=\mathrm{H}, \mathrm{R}^{2}=2 \mathrm{NM}\end{array}$ & $\begin{array}{l}\text { 3: } 4^{\prime}-2 N M, R^{1}=2 N M, R^{2}=R^{3}=R^{4}=H \\
\text { 4: } 5-2 N M, R^{1}=R^{2}=R^{4}=H, R^{3}=2 N M \\
\text { 5: } 6-2 N M, R^{1}=R^{2}=R^{3}=H, R^{4}=2 N M \\
\text { 6: } 3^{\prime}, 4^{\prime}-2 N M, R^{1}=R^{2}=2 N M, R^{3}=R^{4}=H \\
\text { 7a: } 3^{\prime}, 6-2 N M, R^{1}=R^{3}=H, R^{2}=R^{4}=2 N M \\
\text { 8: } 4^{\prime}, 5-2 N M, R^{1}=R^{3}=2 N M, R^{2}=R^{4}=H \\
\text { 9: } 4^{\prime}, 6-2 N M, R^{1}=R^{4}=2 N M, R^{2}=R^{3}=H \\
\text { 10a: } 3^{\prime}, 4^{\prime}, 6-2 N M, R^{1}=R^{2}=R^{4}=2 N M, R^{3}=H \\
11: 3^{\prime}, 4^{\prime}, 5,6-2 N M, R^{1}=R^{2}=R^{3}=R^{4}=2 N M\end{array}$ \\
\hline
\end{tabular}

Figure 1. Structure of the prepared 2-naphthylmethylene (2NM) neamine derivatives.

Scheme 1. General Method Used for the Preparation of the 3',6-Di- (7) and 3',4',6-Trialkylated (10) Neamine Derivatives

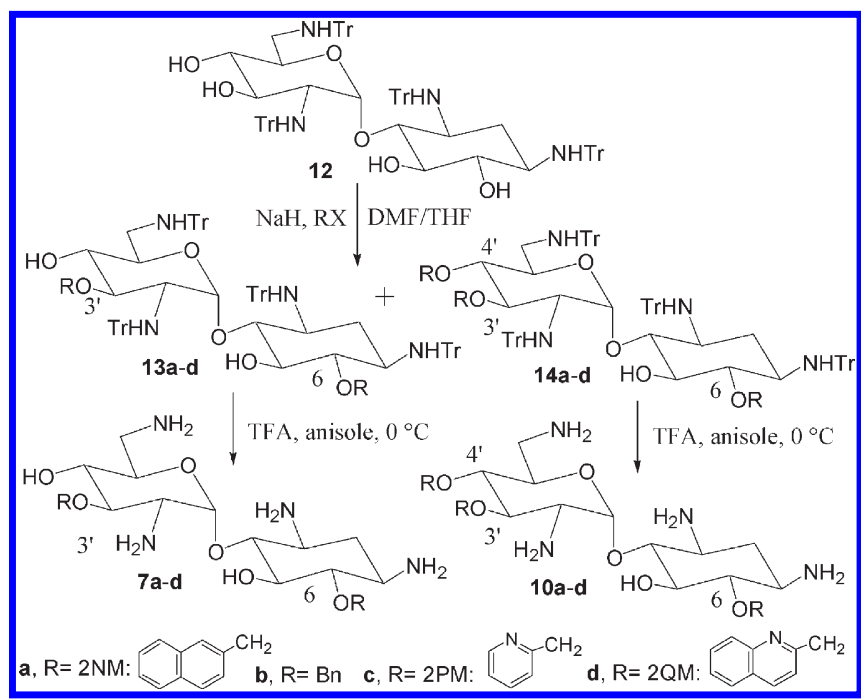

The $4^{\prime}$-mono-2-naphthylmethylene $\left(4^{\prime}-2 \mathrm{NM},{ }^{a} 3\right)$, the 5-2NM (4), and the 4',5-2NM (8) derivative (Figure 1) were synthesized from compound $\mathbf{1 2}$ (Scheme 1) according to the methodology previously described.

The difference in the stability of the $O-2 \mathrm{NM}$ and the $N$-trityl groups under acidic conditions allowed the preparation of the $3^{\prime}, 6-2 \mathrm{NM}$ (7a) and the $3^{\prime}, 4^{\prime}, 6-2 \mathrm{NM}$ (10a) derivatives from 12 in two steps: (i) alkylation of the hydroxyl fonctions and (ii) selective removal of the trityl groups under acidic conditions (Scheme 1). The reaction of $\mathbf{1 2}$ with 2-bromomethylnaphthalene (2NMBr) led to a mixture (1:1) of the tritylated $3^{\prime}, 6-2 \mathrm{NM}$ (13a) and $3^{\prime}, 4^{\prime}, 6-2 \mathrm{NM}$ (14a) derivatives in $40 \%$ and $38 \%$ yields, respectively. Their treatment with TFA/anisole at $0{ }^{\circ} \mathrm{C}$ allowed the selective detritylation leading to $7 \mathbf{a}(70 \%)$ and 10a (65\%), which appeared soluble in water.

The $3^{\prime}, 4^{\prime}, 5,6-2 \mathrm{NM}$ derivative 11 (Figure 1) was prepared by alkylation of $\mathbf{1 2}$ with $2 \mathrm{NMBr}$ in excess and removal of the trityl groups $(40 \%)$. Two other di2NM derivatives, the $3^{\prime}, 4^{\prime}-2 \mathrm{NM}(6)$ and $4^{\prime}, 6-2 \mathrm{NM}(9)$ isomers, were prepared from 14a and 12, respectively. The instability of the $2 \mathrm{NM}$ ethers in TFA and the highest reactivity of the 6-alcoholate function of 12 observed in polar solvents suggested a high sensitivity of the $6-O-2 \mathrm{NM}$ group to TFA. ${ }^{9}$ Therefore, it could be

\footnotetext{
${ }^{a}$ Abbreviations: AAC, aminoglycoside $N$-acetyltransferase; ax, axial; ANT, aminoglycoside $O$-nucleotidyltransferase; APH, aminoglycoside $O$-phosphoryltransferase; 2NM, 2-naphthylmethylene; DCM, dichloromethane; eq, equatorial; np, naphthyl; OM, outer membrane; py, pyridinyl; 2PM, 2-pyridylmethylene; qui, quinolyl; 2QM, 2-quinolylmethylene; MRSA, methicillin resistant S. aureus; VRSA, vancomycin resistant $S$. aureus.
}

possible to prepare $\mathbf{6}$ from $\mathbf{1 4 a}$ through the removal under acidic conditions of the trityl and the 6-2NM groups. 14a was treated with TFA increasing both the temperature (rt) and the reaction time in comparison to the conditions leading to 10a from 14a. 6 was isolated as the major product ( $51 \%)$. The 4',6-2NM derivative 9 was prepared from 12 in three steps: (i) protection of the $3^{\prime}-\mathrm{OH}$ function through reaction with $\mathrm{PMB}$ chloride in the presence of $\mathrm{NaH}$ in toluene in order to slow down the velocities of alkylation of the alcoholate functions in comparison to the DMF/THF mixture $(55 \%)$, (ii) $4^{\prime}$ - and $6-O$-alkylations with $2 \mathrm{NMBr}$ in $\mathrm{DMF}$, and (iii) removal of the trityl and $3^{\prime}$-PMB groups under acidic conditions ( $15 \%$ for the two last steps). The low yield can be explained by the sensitivity of the $4^{\prime}$ - and 6-2NM ether groups to TFA.

The $3^{\prime}$-2NM derivative 2 was obtained as a minor product through the partial deprotection of the tetratrityl intermediate 13a $(22 \%)$ under the conditions used previously for the preparation of $\mathbf{6}$. To prepare the 6-2NM derivative 5 from $\mathbf{1 2}$ and $2 \mathrm{NMBr}$, the proportion of DMF in the DMF/THF mixture previously used for the preparation of $\mathbf{1 3 a}$ and $\mathbf{1 4 a}$ from 12 was increased from 1:9 to $1: 1{ }^{9}$ In the presence of $\mathrm{NaH}, 12$ reacted to lead mainly to the tetratrityl 6-2NM derivative isolated in low yield $(12 \%, 12$ was principally recovered). The resulting compound was detritylated in TFA at $0{ }^{\circ} \mathrm{C}$ to give the $6-2 \mathrm{NM}$ derivative $5(82 \%)$.

To evaluate the role of the naphthyl ring in the antibiotic effects, the 2NM groups in $7 \mathbf{a}$ and $\mathbf{1 0 a}$ were replaced by benzyl (Bn), 2-pyridylmethylene (2PM), or 2-quinolylmethylene (2QM) groups (Scheme 1). The phenyl and pyridyl rings were selected for their weak stacking in nucleic acids. The diBn (7b, 34\%) and triBn (10b, 45\%), the di2PM (7c, 24\%) and tri2PM (10c, 3\%), and the di2QM (7d, 42\%) and tri2QM (10d, 4\%) derivatives were obtained according to the methodology developed for preparing $7 \mathbf{a}$ and 10a. The low yields in 2PM and 2QM derivatives resulted from the sensitivity of the corresponding ether groups to TFA.

Antibiotic Activity. The neamine derivatives synthesized were evaluated against Staphylococcus aureus, sensitive and resistant strains expressing resistance pumps (NorA or MsrA), inactivating enzymes like APH2" $2^{\prime \prime}$ AC6 ${ }^{\prime}, \mathrm{APH} 3^{\prime}$, or ANT4' or against MRSA and VRSA resistant to methicillin and vancomycin, respectively (Table 1). Their effects against Gram (-), Acinetobacter lwoffi, Pseudomonas aeruginosa, Klebsiella pneumoniae, and Escherichia coli sensitive and resistant strains, expressing aminoglycoside-modifying enzymes, efflux pumps (Table 2), or r-methylase were also determined.

On $S$. aureus, in the $2 \mathrm{NM}$ series, the four mono derivatives $(\mathbf{2}, \mathbf{3}, \mathbf{4}, \mathbf{5})$ appeared totally inefficient (Table 1$)$. In contrast, the $3^{\prime}, 6-2 \mathrm{NM}(\mathbf{7 a})$ and $3^{\prime}, 4^{\prime}, 6-2 \mathrm{NM}(\mathbf{1 0 a})$ derivatives were active and for the latter showed remarkable activity against MRSA and VRSA as well as S. aureus expressing APH $3^{\prime}$ and ANT4', toward which neomycin B was inactive. On Gram (-) bacteria, 7a showed no or only moderate antimicrobial effects (Table 2), whereas $\mathbf{1 0 a}$ revealed an antibacterial activity (MIC $=4-16 \mu \mathrm{g} / \mathrm{mL}$ ) both on Enterobacteriaceae and non-Enterobacteriacea including $P$. aeruginosa expressing efflux pumps (Tables 2 and 3). This derivative was also active $[\mathrm{MIC}=4-8 \mu \mathrm{g} / \mathrm{mL}]$ on strains expressing r-methylase (Citrobacter amalonaticus arm 06AB0010, E. coli 06AB003 arm, Enterobacter aerogenes 06АB008 arm) against which gentamicin, amikacin, and tobramycin were totally inactive $(\mathrm{MIC}>128 \mu \mathrm{g} / \mathrm{mL})$. Increasing the number of naphthyl to 
Table 1. Minimum Inhibitory Concentrations against Different Staphylococcus aureus Strains for the Neamine Derivatives, Neomycin B, and Neamine

\begin{tabular}{|c|c|c|c|c|c|c|c|c|}
\hline \multirow[b]{2}{*}{ aminoglycosides } & \multicolumn{8}{|c|}{$\mathrm{MIC} \mu \mathrm{g} / \mathrm{mL}$} \\
\hline & $\begin{array}{c}\text { ATCC } \\
25923\end{array}$ & $\begin{array}{l}\text { pump } \\
\text { NorA }\end{array}$ & $\begin{array}{l}\text { pump } \\
\text { MsrA }\end{array}$ & 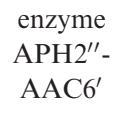 & $\begin{array}{l}\text { enzyme } \\
\text { APH }^{\prime}\end{array}$ & $\begin{array}{l}\text { enzyme } \\
\text { ANT4' }\end{array}$ & $\begin{array}{c}\text { ATCC } \\
33592 \\
\text { HA-MRSA }\end{array}$ & $\begin{array}{l}\text { VRSA- } \\
\text { VRS-2 }\end{array}$ \\
\hline neomycin B & 2 & 1 & 2 & 1 & $>128$ & 32 & $>128$ & 128 \\
\hline neamine 1 & 32 & 32 & 16 & 16 & $>128$ & $>128$ & $>128$ & $>128$ \\
\hline $3^{\prime}$-mono $2 \mathrm{NM} 2$ & $>128$ & $>128$ & $>128$ & $>128$ & 128 & $>128$ & ND & ND \\
\hline $4^{\prime}$-mono2NM 3 & $>128$ & $>128$ & $>128$ & $>128$ & $>128$ & $>128$ & ND & ND \\
\hline 5-mono2NM 4 & $>128$ & $>128$ & $>128$ & $>128$ & $>128$ & $>128$ & ND & ND \\
\hline 6-mono2NM 5 & $>128$ & $>128$ & $>128$ & $>128$ & $>128$ & $>128$ & $>128$ & ND \\
\hline $3^{\prime}, 4^{\prime}$-di2NM 6 & 4 & 8 & 8 & 8 & 4 & 8 & 8 & 4 \\
\hline $3^{\prime}, 6$-di2NM 7a & 8 & 8 & 8 & 8 & 4 & 8 & 16 & 16 \\
\hline $4^{\prime}, 5$-di2NM 8 & 64 & 128 & 128 & 128 & 32 & 128 & 64 & 64 \\
\hline 4',6-di2NM 9 & 32 & 32 & 32 & 32 & 16 & 16 & 64 & 32 \\
\hline $3^{\prime}, 4^{\prime}, 6$-tri2NM 10a & 4 & 4 & 4 & 4 & 2 & 4 & 2 & 4 \\
\hline $3^{\prime}, 4^{\prime}, 5,6$-tetra $2 \mathrm{NM} 11$ & 32 & 64 & 64 & 64 & 32 & 64 & 32 & 64 \\
\hline $3^{\prime}, 6-\operatorname{diBn} 7 \mathbf{b}$ & $>128$ & $>128$ & $>128$ & $>128$ & $>128$ & $>128$ & ND & ND \\
\hline $3^{\prime}, 6$-di2PM 7c & $>128$ & $>128$ & $>128$ & $>128$ & $>128$ & $>128$ & ND & ND \\
\hline $3^{\prime}, 6$-di2QM 7d & $>128$ & $>128$ & $>128$ & $>128$ & $>128$ & $>128$ & ND & ND \\
\hline $3^{\prime}, 4^{\prime}, 6$-triBn 10b & $>128$ & $>128$ & $>128$ & $>128$ & $>128$ & $>128$ & $>128$ & 64 \\
\hline $3^{\prime}, 4^{\prime}, 6$-triPM 10c & $>128$ & $>128$ & $>128$ & $>128$ & $>128$ & $>128$ & ND & ND \\
\hline $3^{\prime}, 4^{\prime}, 6$-tri2QM 10d & 128 & $>128$ & $>128$ & 128 & 64 & $>128$ & 64 & 64 \\
\hline
\end{tabular}

Table 2. Minimum Inhibitory Concentrations against Selected Bacterial Gram (-) Susceptible and Resistant Strains through Enzymatic Modification and $\operatorname{Efflux}^{a}$

\begin{tabular}{|c|c|c|c|c|c|c|c|c|c|}
\hline \multirow[b]{3}{*}{ aminoglycosides } & \multicolumn{9}{|c|}{ MIC $\mu \mathrm{g} / \mathrm{mL}$} \\
\hline & \multicolumn{2}{|c|}{ A. lwoffi } & \multicolumn{3}{|c|}{ P. aeruginosa } & \multirow{2}{*}{$\frac{\text { K. pneumoniae }}{\mathrm{f}}$} & \multicolumn{3}{|c|}{ E. coli } \\
\hline & $\mathrm{a}$ & $\mathrm{b}$ & $\mathrm{c}$ & $\mathrm{d}$ & $\mathrm{e}$ & & $\mathrm{g}$ & $\mathrm{h}$ & $\mathrm{i}$ \\
\hline gentamicin & 0.5 & $4-8$ & 1 & $>128$ & 4 & 8 & $<0.5-1$ & 1 & $64-128$ \\
\hline amikacin & 0.5 & $>128$ & $2-4$ & 4 & $8-16$ & 0.5 & 4 & 32 & 2 \\
\hline tobramycin & 0.5 & 1 & 0.5 & 128 & 1 & 4 & 0.5 & 32 & 64 \\
\hline neomycin B & 0.5 & $>128$ & 64 & 128 & 32 & $16-32$ & 2 & 4 & 32 \\
\hline neamine 1 & 2 & $>128$ & $>128$ & $>128$ & $>128$ & $32-64$ & 32 & $>128$ & 32 \\
\hline $3^{\prime}, 4^{\prime}-\operatorname{di} 2 \mathrm{NM} 6$ & 8 & $>128$ & 32 & $>128$ & $>128$ & $>128$ & 32 & 16 & 16 \\
\hline $3^{\prime}, 6-$ di2NM 7 & 64 & $>128$ & 128 & 128 & $>128$ & $128->128$ & 64 & 64 & 64 \\
\hline $4^{\prime}, 5$-di2NM 8 & 32 & $>128$ & 128 & $>128$ & $>128$ & $>128$ & 128 & 128 & 128 \\
\hline 4',6-di2NM 9 & 64 & $>128$ & $>128$ & $>128$ & $>128$ & $>128$ & 128 & 64 & 128 \\
\hline $3^{\prime}, 4^{\prime}, 6$-tri2NM $10 \mathrm{a}$ & 4 & 32 & 8 & 8 & 4 & 16 & 16 & 4 & 4 \\
\hline $3^{\prime}, 4^{\prime}, 5,6$-tetra2NM 11 & 32 & $>128$ & 64 & 64 & 64 & 128 & 128 & 64 & 64 \\
\hline $3^{\prime}, 4^{\prime}, 6-\operatorname{triBn} 10 \mathrm{~b}$ & $>128$ & $>128$ & $>128$ & $>128$ & $>128$ & $>128$ & $>128$ & $>128$ & $>128$ \\
\hline $3^{\prime}, 4^{\prime}, 6-$ tri2QM 10d & 128 & $>128$ & $>128$ & $>128$ & $>128$ & $>128$ & $>128$ & $>128$ & $>128$ \\
\hline
\end{tabular}

${ }^{a}$ a: ATCC 17925; b: AI.88-483 APH3'-VIa; c: ATCC 27853; d: Psa.F03 AAC6'-IIa; e: PA22 (PT629) surexp MexXY; f: ATCC 700603; g: ATCC 25922 ; h: PAZ505H8101 AAC6'-IIb; i: L58058.1 ANT2"'-IIa.

four with 11 resulted in a strong or complete loss of activity both on Gram (+) (Table 1) and Gram (-) (Tables 2, 3) bacteria.

Regarding the importance of the position of the $2 \mathrm{NM}$ groups in the di2NM neamine derivatives, with the $3^{\prime}, 4^{\prime}$ $2 \mathrm{NM}$ derivative $\mathbf{6}$, we observed antibacterial effects against the $S$. aureus strains similar to those of the $3^{\prime}, 6$-isomer $7 \mathbf{a}$ (Table 1). Also like 7a, 6 appeared inefficient against Gram (-) strains (Table 2). The $4^{\prime}, 5-2 \mathrm{NM}$ derivative 8 and the 4',6-2NM isomer 9 were less active or inefficient both against $S$. aureus and Gram (-) bacteria (Tables 2 and 3 ).

The replacement of the naphthyl rings in $7 \mathbf{a}$ and $10 \mathbf{a}$ by benzyl, pyridyl, or quinolyl rings led to the complete disappearance of the antibiotic activities both on Gram $(+)$ and Gram (-) bacteria (7b-d: Table 1; 10b,d: Tables 2 and 3).

Alteration of Protein Synthesis. The ability of 10a to decrease the incorporation of ${ }^{3} \mathrm{H}$ leucine ${ }^{10}$ (Figure 2) was determined in comparison to neamine $\mathbf{1}$, neomycin $\mathrm{B}$, and aztreonam, a monolactam antibiotic acting on the cell wall. As expected, both neamine and aztreonam had no effect on synthesis of proteins. In contrast, the inhibition induced by neomycin B was around $40 \%$ at the MIC and reached $95 \%$ at 10-fold the MIC. 10a also decreased the incorporation of radiolabeled leucine, but the concentrations required to obtain a given effect were greater than those required with neomycin B. Ten-fold the MIC led to $\sim 65 \%$ inhibition. The inhibitory profile of $\mathbf{1 0 a}$ was quite similar to that of polymyxin E (also known as colistin), ${ }^{11}$ a bactericidal antibiotic acting on bacterial membrane with which 30 and around $95 \%$ of decrease in incorporation were observed at 5- and 10-fold MIC, respectively (Figure 2).

Isothermal Titration Calorimetry (ITC). The binding of compounds $7 \mathbf{a}$ and 10a to a model bacterial rRNA A site was evaluated using ITC. ${ }^{12}$ Only unspecific binding ${ }^{12}\left(K_{\mathrm{d}}\right.$ in the $10 \mu \mathrm{M}$ range) was observed for each compound, whereas a specific interaction $\left(K_{\mathrm{d}}=1.55 \mu \mathrm{M}\right)$ was obtained in the same experimental conditions with neomycin B (see as Supporting Information). ${ }^{13}$

\section{Discussion and Conclusion}

Sixteen amphiphilic neamine derivatives carrying one to four arylmethylene groups were prepared and evaluated for 
Table 3. Minimum Inhibitory Concentrations against P. aeruginosa Susceptible WT and Resistant through Overexpression of Efflux Pump for Selected Natural Aminoglycosides and Neamine Derivatives ${ }^{a}$

\begin{tabular}{|c|c|c|c|c|c|c|c|c|}
\hline \multirow[b]{2}{*}{ aminoglycosides } & \multicolumn{8}{|c|}{$\mathrm{MIC} \mu \mathrm{g} / \mathrm{mL}$} \\
\hline & a & $\mathrm{b}$ & $\mathrm{c}$ & $\mathrm{d}$ & $\mathrm{e}$ & $\mathrm{f}$ & $\mathrm{g}$ & $\mathrm{h}$ \\
\hline gentamicin & 1 & 2 & 1 & 1 & 1 & 4 & $<0.125$ & $<0.125$ \\
\hline amikacin & $2-4$ & $2-4$ & 2 & $2-4$ & 2 & $8-16$ & 0.5 & 1 \\
\hline tobramycin & 0.5 & 0.5 & 0.5 & $<0.25$ & 0.5 & 1 & $<0.25$ & $<0.25$ \\
\hline neomycinB & $64-128$ & 4 & 8 & 4 & 4 & 32 & 2 & 4 \\
\hline neamine 1 & $>128$ & $>128$ & $>128$ & $>128$ & $>128$ & $>128$ & 128 & 128 \\
\hline $3^{\prime} 4^{\prime}-\operatorname{di} 2 \mathrm{NM} 6$ & $16-32$ & 64 & 16 & 8 & 64 & $>128$ & 8 & 8 \\
\hline $3^{\prime}, 6$-di2NM 7a & 128 & 128 & 32 & 4 & $>128$ & $>128$ & 4 & 4 \\
\hline $4^{\prime}, 5-\operatorname{di} 2 \mathrm{NM} 8$ & $>128$ & $>128$ & $>128$ & $>128$ & $>128$ & $>128$ & 16 & 16 \\
\hline $4^{\prime}, 6-\operatorname{di} 2 \mathrm{NM} 9$ & $>128$ & $>128$ & 128 & 16 & $>128$ & $>128$ & 32 & 16 \\
\hline $3^{\prime}, 4^{\prime}, 6$-tri2NM 10a & $4-8$ & $8-16$ & 4 & 4 & 4 & 4 & 4 & 4 \\
\hline $3^{\prime}, 4^{\prime}, 5,6$-tetra2NM 11 & 64 & 64 & 64 & 64 & 64 & 64 & 64 & 64 \\
\hline $3^{\prime}, 4^{\prime}, 6-\operatorname{triBn} 10 \mathrm{~b}$ & $>128$ & $>128$ & $>128$ & $>128$ & $>128$ & $>128$ & 64 & 64 \\
\hline $3^{\prime}, 4^{\prime}, 6-$ tri2QM 10d & $>128$ & $>128$ & $>128$ & $>128$ & $>128$ & $>128$ & 64 & 64 \\
\hline
\end{tabular}

${ }^{a}$ a: ATCC 27853 WT; b: PA07 (PAO1) WT; c: PA02 surexp MexCD; d: PA03 surexp MexEF; e: PA21 (MutGr1) surexp MexAB; f: PA22 (PT629) surexp MexXY; g: PA405 (PA0509.5) surexp TriABC and deleted for MexAB, MexCD, MexEF, MexXY; h: PA406 (PA0 $1095 \# 1)$ deleted for MexAB, MexCD, MexEF, MexXY, TriABC.

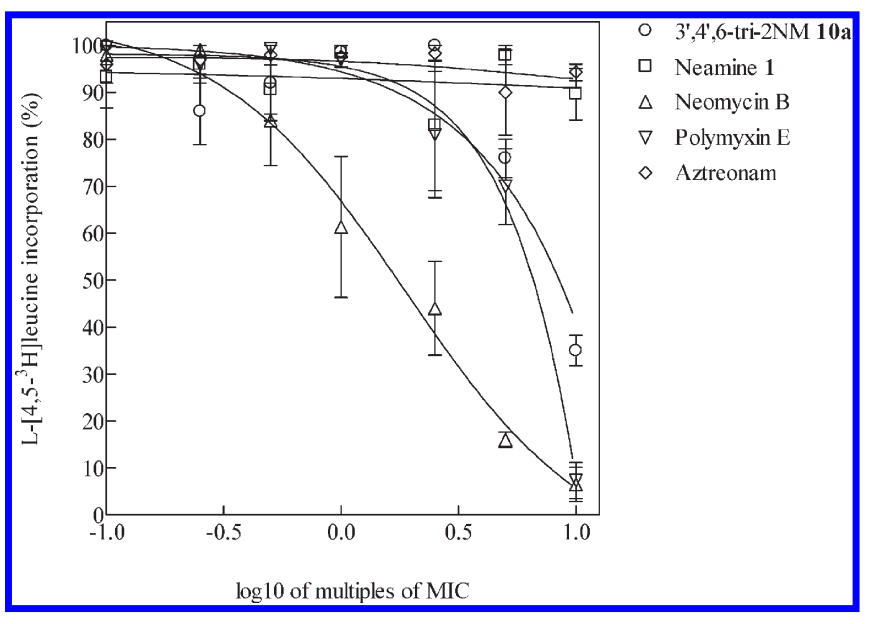

Figure 2. Effects of the $3^{\prime}, 4^{\prime}, 6$-tri2NM neamine derivative 10a, neamine $\mathbf{1}$, neomycin $\mathrm{B}$, polymyxin $\mathrm{E}$, and aztreonam on protein synthesis of $P$. aeruginosa ATCC 27853 . L- $\left[4,5-{ }^{3} \mathrm{H}\right]$ Leucine incorporation into proteins was measured after exposure to $0.1,0.25$, $0.5,1,2.5,5$, and 10 times MIC. The ordinate shows the percentage of incorporation of leucine expressed in \% of control. Values are mean $(n=3)$ determinations. Error bars represent standard deviations.

their antibacterial properties. Among them, the $3^{\prime}, 4^{\prime}-2 \mathrm{NM}$ (6), 3',6-2NM (7a), and 3', 4',6-2NM (10a) derivatives showed strong antimicrobial activity against sensitive and resistant $S$. aureus, including MRSA and VRSA toward which neomycin B is totally inactive. When tested against sensitive or resistant Gram (-) organisms, 10a appeared to be the sole promising agent. It showed MIC values ranging from 4 up to $16 \mu \mathrm{g} / \mathrm{mL}$ against a large panel of sensitive and resistant strains including bacteria expressing rRNA methylases. This feature is particularly exciting because methylation of $16 \mathrm{~S}$ rRNA is a serious threat to aminoglycosides through the action of plasmid-mediated methyltransferase enzymes and spreading to different species. ${ }^{4}$

The antibacterial effects of the aminoglycosides used as drugs result from their ability to be taken up by the bacteria together with their affinity for rRNA. The conjugation of neamine to $2 \mathrm{NM}$ hydrophobic groups leading to more lipophilic compounds than neamine should enhance the penetration of the corresponding derivatives in the phospholipid bilayer of bacteria, resulting in either increased uptake or destabilization of the lipid membrane. The presence of the $2 \mathrm{NM}$ groups in the active compounds also should modify the affinity of the neamine core for different RNA sequences through steric hindrance, minor groove binding, and/or stacking.

Regarding potential structure/activity relationships, the four mono2NM derivatives $\mathbf{2}-\mathbf{5}$ were inefficient as antibiotic agents and the tetra2NM derivative $\mathbf{1 1}$ showed weak antibacterial effects. In contrast, the presence of two or three $2 \mathrm{NM}$ groups in the neamine derivatives led to active compounds. On $S$. aureus, among the disubstituted derivatives synthesized, the most active ones are the $3^{\prime}, 4^{\prime}-2 \mathrm{NM}(\mathbf{6})$ and $3^{\prime}, 6-2 \mathrm{NM}$ (7a) derivatives. Their MICs were much lower than those of the 4',5-2NM (8) and 4',6-2NM (9) isomers. The replacement of the $2 \mathrm{NM}$ moieties in $7 \mathbf{a}$ by benzyl, 2PM, and 2QM groups led to the disappearance of the antimicrobial effects. These data probably exclude a nonspecific detergent effect because the antimicrobial effects observed with the di2NM derivatives depend on the positions of the 2NM groups. Also, a minor change in the structure, i.e., the replacement of the $2 \mathrm{NM}$ moieties in 7a by 2QM groups led to the disappearance of the antimicrobial effects. This conclusion is in accord with previous data obtained with neomycin conjugates to fatty acids, cholesterol, and pyrene. ${ }^{14}$ These compounds have shown antibacterial effects against Gram $(+)$ bacteria strictly dependent on the nature of the lipidic moiety.

Only the tri2NM derivative 10a is active both on Gram $(+)$ and Gram ( - ) bacteria. The presence of three $2 \mathrm{NM}$ groups is necessary for obtaining antimicrobial effects against Gram (-) bacteria. Also, the replacement of the 2NM groups by benzyl, 2PM, or 2QM groups led to the disappearance of the antibiotic effects against both Gram $(+)$ and Gram $(-)$ bacteria, suggesting the critical role of the naphthyl rings. The structure of the substituents and their number appear therefore to be critical parameters.

Several features of the active neamine derivatives prepared should be put forward.

First, the affinity of $\mathbf{7 a}$ and $\mathbf{1 0 a}$ for a model bacterial ribosomal A site measured by microcalorimetry (ITC) appeared to be weak and aspecific in comparison to the strong binding of neomycin B observed. This result and the low inhibition of leucine incorporation in proteins of $P$. aeruginosa induced by 10a in comparison to neomycin B (Figure 2) suggest a weak binding of 10a to rRNA. However, a binding 
of 7a and 10a to a RNA sequence different from the A site, leading to strong disruption of protein synthesis, remains possible in Gram $(+)$ bacteria.

Second, if the antimicrobial activity of 10a against Gram $(+)$ and Gram ( - ) bacteria results, at least in part, from a binding to the bacterial membranes and a corresponding membrane destabilization, the hydrophobic/hydrophilic balance of the active derivative should be a critical parameter for the binding to membranes and lipid bilayer destabilization. This assumption is in agreement with the observed SAR and the critical role of the number of $2 \mathrm{NM}$ groups observed.

Third, the loss of activity of the di2NM derivatives $\mathbf{6 , 7 a , 8}$ and $\mathbf{9}$ and the poor activity of the tetra2NM derivative $\mathbf{1 1}$ against Gram ( $(-)$ bacteria could result from the incapacity of these compounds to cross the outer membrane of these bacteria. The uptake of aminoglycosides through the outer membrane of Gram ( - ) bacteria is related to their ability to displace $\mathrm{Ca}^{2+}$ or $\mathrm{Mg}^{2+}$ from LPS, destroying the crossbridging and destabilizing the outer membrane bilayer structure. ${ }^{15}$ Thus, $\mathbf{1 0 a}$ could be the sole derivative prepared which has the optimum lipophily/hydrophily balance to destabilize the outer membrane bilayer structure, probably by increasing the self-promoted uptake.

Fourth, the inhibition of the leucine incorporation in proteins of $P$. aeruginosa induced by $\mathbf{1 0 a}$ was similar to that observed with polymyxin $\mathrm{E}$ (colistin), an antibacterial used in clinics to control chronic lung infections of multidrug resistant $P$. aeruginosa isolates in cystic fibrosis patients. ${ }^{11}$ Recent AFM studies suggested that polymyxin E prevents $P$. aeruginosa proliferation by repressing cell division. ${ }^{16}$ The exact mechanism of action of colistin is however not fully understood and could be more complex than originally assumed, $i$. e., binding to lipid A, release of LPS, disruption of the outer membrane, enhancement of self-promoted uptake, interaction with the cytoplasmic membrane, and increase of the permeability of the cell membrane. The formation of molecular contacts between the inner and outer membranes of the bacteria leading to lipid exchange resulting in loss of the compositional specificity of the membranes and osmotic instability, ${ }^{17}$ together with increase in the rigidity of the bacterial cell wall and loss of LPS or surface proteins, could also contribute to the bactericidal effect of colistin. Further studies have to be done to know if the $3^{\prime}, 4^{\prime}, 6-2 \mathrm{NM}$ derivative 10a has a similar mechanism of action.

In conclusion, interactions with the bacterial cell membrane are probably responsible for the excellent antimicrobial activity of 10a in Gram (-) bacteria. Further studies are in progress with the aim to determine at the molecular level the binding modes and constants of our derivatives to bacterial lipids and to different rRNA sequences.

\section{Experimental Section}

Chemistry. General procedures. Procedure A was developed for the preparation of the $3^{\prime}, 6$-di- $O$ - and $3^{\prime}, 4^{\prime}, 6$-tri- $O$-alkylated neamine derivatives from the tetratrityl derivative 12: To a solution of $\mathbf{1 2}^{8}$ ( 1 equiv) in DMF/THF (1/9) under argon were added $\mathrm{NaH}(60 \%, 4$ equiv) and then, after $15 \mathrm{~min}$ at $\mathrm{rt}$, the halide (3 equiv). The mixture was stirred for $24 \mathrm{~h}$ at $\mathrm{rt}$ and then DCM was added. The organic solution was washed with a saturated aqueous $\mathrm{NH}_{4} \mathrm{Cl}$ solution, water, and then brine before drying over $\mathrm{MgSO}_{4}$, filtration, and evaporation. The residue was chromatographed on alumina with cyclohexane/DCM to give the tetratrityl $3^{\prime}, 6-O$ - (13) and $3^{\prime}, 4^{\prime}, 6-O$-arylmethylene (14) derivatives.
Procedure B was used for the removal of the trityl groups: The protected compound (13 or $\mathbf{1 4})$ was dissolved at $0{ }^{\circ} \mathrm{C}$ in DCM/TFA $(1 / 1)$ in the presence of anisole $(50 \mathrm{mg} / \mathrm{mL})$. After 2 $\mathrm{h}$, the solvents were evaporated. After addition of water and $\mathrm{Et}_{2} \mathrm{O}$, the aqueous phase was washed twice with $\mathrm{Et}_{2} \mathrm{O}$ and evaporated. The residue was chromatographed on $\mathrm{C} 18$ reversed phase to lead to the TFA salts 7 and 10, respectively.

Mono-2NM (2-5) and 4',5-di2NM (8) Derivatives. 3'-Mono$O$-[(2-naphthyl)methyl] neamine derivative 2 : prepared through the overdeprotection of $13 \mathrm{a}$, leading to removal of the $2 \mathrm{NM}$ group at position 6 according to procedure B at rt during $3 \mathrm{~h}$. After purification on $\mathrm{C} 18$ reversed phase, the compound $7 \mathbf{a}$ $\left(3^{\prime}, 6-\right.$ di2 $\mathrm{NM}$ ) and a mixture of 2 and $\mathbf{5}$ (6-mono2NM) were obtained. Both mono2NM neamine derivatives 2 and 5 were separated by chromatography on silica gel with $\mathrm{EtOH} / \mathrm{H}_{2} \mathrm{O}$ / $\mathrm{NH}_{3}(90 / 10 / 20, \mathrm{v} / \mathrm{v} / \mathrm{v})$. After concentration of the fractions, the trifluoroacetate of $\mathbf{2}$ was converted to the chlorhydrate salt by ion exchange chromatography; $22 \%$ yield. ${ }^{1} \mathrm{H}$ NMR $(400 \mathrm{MHz}$, $\left.\mathrm{D}_{2} \mathrm{O}\right) \delta$ 7.95-8.02 (m, 4H, H-np), 7.58-7.65 (m, 3H, H-np), 5.95 $\left(\mathrm{d}, J=3.6 \mathrm{~Hz}, 1 \mathrm{H}, \mathrm{H}_{-1}^{\prime}\right), 5.17\left(\mathrm{~d}, J=11.0 \mathrm{~Hz}, 1 \mathrm{H}, \mathrm{CH}_{2}-\mathrm{np}\right)$, $5.01\left(\mathrm{~d}, J=11.0 \mathrm{~Hz}, 1 \mathrm{H}, \mathrm{CH}_{2}-\mathrm{np}\right), 4.16(\mathrm{dd}, J=8.8$ and 10.6 $\left.\mathrm{Hz}, 1 \mathrm{H}, \mathrm{H}-3^{\prime}\right), 4.09$ (ddd, $J=3.2,7.1$, and $10.0 \mathrm{~Hz}, 1 \mathrm{H}, \mathrm{H}-5^{\prime}$ ), $4.00(\mathrm{dd}, J=9.8 \mathrm{~Hz}, 1 \mathrm{H}, \mathrm{H}-4), 3.75\left(\mathrm{dd}, J=9.7 \mathrm{~Hz}, 1 \mathrm{H}, \mathrm{H}-4^{\prime}\right)$, $3.73(\mathrm{dd}, J=9.3 \mathrm{~Hz}, 1 \mathrm{H}, \mathrm{H}-5), 3.53-3.63$ (m, 3H, H-3, H-6, H$\left.2^{\prime}\right), 3.49\left(\mathrm{dd}, J=3.3\right.$ and $\left.13.6 \mathrm{~Hz}, 1 \mathrm{H}, \mathrm{H}-6^{\prime} \mathrm{b}\right), 3.37(\mathrm{dd}, J=4.2$ and $12.3 \mathrm{~Hz}, 1 \mathrm{H}, \mathrm{H}-1), 3.32(\mathrm{dd}, J=7.1$ and $13.6 \mathrm{~Hz}, 1 \mathrm{H}$, H-6'a), 2.52 (ddd, $J=4.2$ and $12.6 \mathrm{~Hz}, 1 \mathrm{H}, \mathrm{H}-2 \mathrm{ax}$ ), 1.91 (ddd, $J=12.6 \mathrm{~Hz}, 1 \mathrm{H}, \mathrm{H}-2 \mathrm{eq}) .{ }^{13} \mathrm{C}$ NMR $\left(100 \mathrm{MHz}, \mathrm{D}_{2} \mathrm{O}\right) \delta 136.3$ and 134.5 (C-np), 130.1, 129.5, 129.3, 129.1, and 128.0 (CH-np), 97.6 (C-1' $), 79.4$ (C-4), $77.4\left(\mathrm{C}-3^{\prime}\right), 76.6\left(\mathrm{C}-5\right.$ and $\mathrm{CH}_{2}$-np), 74.1 (C-6), 72.7 and $71.3\left(\mathrm{C}-4^{\prime}\right.$ and $\left.\mathrm{C}-5^{\prime}\right), 54.4\left(\mathrm{C}-2^{\prime}\right), 51.2$ and 50.0 (C-1 and C-3), $41.5\left(\right.$ C-6 $\left.^{\prime}\right), 29.9$ (C-2). LRMS (ESI $\left.{ }^{+}\right) m / z: 463$ $[\mathrm{M}+\mathrm{H}]^{+}, 301,163,161,141 . \operatorname{HRMS}\left(\mathrm{ESI}^{+}\right) m / z:[\mathrm{M}+\mathrm{H}]^{+}$ calculated 463.2557 , found $463.2555,[\mathrm{M}+\mathrm{Na}]^{+}$calculated 485.2376, found 485.2386; purity: 94\% (HPLC).

$4^{\prime}$-Mono- $O$ - (3), 5-mono- $O$ - (4), and 4',5-di- $O$-[(2-naphthyl)methyl] (8) neamine derivatives: synthesized according to the method previously described for the preparation of $4^{\prime}-$ or 5-mono- $O$ - and $4^{\prime}, 5$-di- $O$-alkylated neamine derivatives. ${ }^{8}$ To a solution of the $N$-tetratritylated $3^{\prime}, 6$-diPMB neamine derivative $^{8}(1.0 \mathrm{~g}, 0.63 \mathrm{mmol})$ in $45 \mathrm{~mL}$ of dry DMF/THF mixture $(1 / 9$, $\mathrm{v} / \mathrm{v})$ under argon was added $\mathrm{NaH}(60 \%, 240 \mathrm{mg}, 6 \mathrm{mmol})$, and after $15 \mathrm{~min}$ stirring at rt TBAI $(237.7 \mathrm{mg}, 0.63 \mathrm{mmol})$ and $2 \mathrm{NMBr}(975 \mathrm{mg}, 4.41 \mathrm{mmol})$. The resulting mixture was stirred for $24 \mathrm{~h}$ at $70^{\circ} \mathrm{C}$, and then DCM was added. The organic phase was washed with an ammonium chloride aqueous saturated solution, water, and then brine before being dried over $\mathrm{MgSO}_{4}$, filtrated, and concentrated under reduced pressure. The residue obtained was chromatographed on alumina gel with a gradient of cyclohexane/DCM from $80 / 20$ to $50 / 50$ to give the mono$O$ - and di- $O$-alkylated-tetra- $N$-tritylated neamine derivatives. Then the three alkylated compounds obtained were treated according to procedure B. 3: $26 \%$ yield. ${ }^{1} \mathrm{H}$ NMR $(400 \mathrm{MHz}$, $\mathrm{CD}_{3} \mathrm{OD}$ ) $\delta 7.81-7.88$ (m, 4H, H-np), 7.44-7.52 (m, 3H, H-np), $\left.5.95\left(\mathrm{~d}, J=3.8 \mathrm{~Hz}, 1 \mathrm{H}, \mathrm{H}^{-}\right)^{\prime}\right), 5.16\left(\mathrm{~d}, J=11.5 \mathrm{~Hz}, 1 \mathrm{H}, \mathrm{CH}_{2^{-}}\right.$ np), 4,82 (d, $J=11.5 \mathrm{~Hz}, 1 \mathrm{H}, \mathrm{CH}_{2}$-np), 4.22 (dd, $J=8.7$ and $\left.10.6 \mathrm{~Hz}, 1 \mathrm{H}, \mathrm{H}-3^{\prime}\right), 4.14$ (ddd, $J=2.5$ and $8.4 \mathrm{~Hz}, 1 \mathrm{H}, \mathrm{H}-5^{\prime}$ ), $4.00(\mathrm{dd}, J=9.8 \mathrm{~Hz}, 1 \mathrm{H}, \mathrm{H}-4), 3,61$ (dd, $J=9.2 \mathrm{~Hz}, 1 \mathrm{H}, \mathrm{H}-5)$, $3.32-3.49$ (m, 4H, H-3, H-6, H2' $\left.2^{\prime}-4^{\prime}\right), 3.27$ (dd, $J=2.5$ and $13.2 \mathrm{~Hz}, 1 \mathrm{H}, \mathrm{H}-6^{\prime} \mathrm{b}$ ), 3.18 (ddd, $J=2.0$ and $12.0 \mathrm{~Hz}, 1 \mathrm{H}, \mathrm{H}-1$ ), $2.90\left(\mathrm{dd}, J=9.4\right.$ and $\left.13.2 \mathrm{~Hz}, 1 \mathrm{H}, \mathrm{H}-6^{\prime} \mathrm{a}\right), 2.44(\mathrm{ddd}, J=4.0$ and $12.5 \mathrm{~Hz}, 1 \mathrm{H}, \mathrm{H}-2 \mathrm{eq}), 1,99$ (ddd, $J=12.0 \mathrm{~Hz}, 1 \mathrm{H}, \mathrm{H}-2 \mathrm{ax}) .{ }^{13} \mathrm{C}$ NMR (100 MHz, CD 3 OD) $\delta 133.1-135.3$ (3C-np), 125.7128.0 (7CH-np), 95.7 (C-1'), 79.1 (C-4'), 77.9 (C-4), 75.8 (C-5), $74.6\left(\mathrm{CH}_{2}-\mathrm{np}\right), 72.9(\mathrm{C}-6), 68.9\left(\mathrm{C}-5^{\prime}\right.$ and $\left.\mathrm{C}-3^{\prime}\right), 54.2\left(\mathrm{C}-2^{\prime}\right), 50.1$ (C-1), 48.7 (C-3), 40.6 (C-6'), 28.4 (C-2). LRMS (DCI) $m / z: 463$ $[\mathrm{M}+\mathrm{H}]^{+}, 323[\mathrm{M}+\mathrm{H}-2 \mathrm{NM}]^{+} . \mathrm{HRMS}\left(\mathrm{ESI}^{+}\right) m / z:[\mathrm{M}+\mathrm{H}]^{+}$ calculated 463.2557 , found $463.2538,[\mathrm{M}+\mathrm{Na}]^{+}$calculated 485.2376, found 485.2385; purity: 93\% (HPLC). 4: 40\% yield. ${ }^{1} \mathrm{H}$ NMR (400 MHz, D 20$) \delta 7.81-7.89$ (m, 4H, H-np), 
7.47-7.50 (m, 3H, H-np), 5.81 (d, $\left.J=3.6 \mathrm{~Hz}, 1 \mathrm{H}, \mathrm{H}-1^{\prime}\right), 5.00$ (d, $\left.J=11.2 \mathrm{~Hz}, 1 \mathrm{H}, \mathrm{CH}_{2}-\mathrm{np}\right), 4.79(\mathrm{~d}, J=11.2 \mathrm{~Hz}, 1 \mathrm{H}$, $\left.\mathrm{CH}_{2}-\mathrm{np}\right), 4.03\left(\mathrm{~m}, 1 \mathrm{H}, \mathrm{H}-3^{\prime}\right), 3.89-3.93\left(\mathrm{~m}, 1 \mathrm{H}, \mathrm{H}-5^{\prime}\right)$, 3.74-3.79 (m, 1H, H-4), 3.56-3.60 (m, 1H, H-5), 3.43-3.50 (m, 2H, H-6, H-4') $3.15-3.32$ (m, 5H, H-2', H-3, H-6'a, H-6' b, H-1), 2.84-2.90 (ddd, 1H, H-2eq), 2.26-2.31 (ddd, 1H, H-2ax). LRMS $\left(\mathrm{ESI}^{+}\right) m / z: 463[\mathrm{M}+\mathrm{H}]^{+}, 323[\mathrm{M}+\mathrm{H}-2 \mathrm{NM}]^{+}$. HRMS $\left(\mathrm{ESI}^{+}\right) \mathrm{m} / z:[\mathrm{M}+\mathrm{H}]^{+}$calculated 463.2557, found 463.2556. 8: $10 \%$ yield. ${ }^{1} \mathrm{H}$ NMR (400 $\left.\mathrm{MHz}, \mathrm{CD}_{3} \mathrm{OD}\right) \delta$ 7.82-7.94 (m, 8H, H-np), 7.45-7.58 (m, 6H, H-np), 5.86 (d, $\left.J=3.0 \mathrm{~Hz}, 1 \mathrm{H}, \mathrm{H}-1^{\prime}\right), 5.26\left(\mathrm{~d}, J=11.0 \mathrm{~Hz}, 1 \mathrm{H}, \mathrm{CH}_{2}-\mathrm{np}\right), 4.97$ (d, $\left.J=11.0 \mathrm{~Hz}, 1 \mathrm{H}, \mathrm{CH}_{2}-\mathrm{np}\right), 4.80-4.95$ (m, 2H, $\left.\mathrm{CH}_{2}-\mathrm{np}\right)$, $4.25-4.33$ (m, 2H, H-3', H-5'), 4.18 (t, $J=9.4 \mathrm{~Hz}, 1 \mathrm{H}, \mathrm{H}-4)$, $3.78(\mathrm{t}, J=8.8 \mathrm{~Hz}, 1 \mathrm{H}, \mathrm{H}-5), 3.71(\mathrm{t}, J=9.5 \mathrm{~Hz}, 1 \mathrm{H}, \mathrm{H}-6), 3.52$ (m br, $1 \mathrm{H}, \mathrm{H}-3), 3.46\left(\mathrm{t}, J=6.0 \mathrm{~Hz}, 1 \mathrm{H}, \mathrm{H}-4^{\prime}\right), 3.41(\mathrm{dd}, J=3.0$ and $\left.7.0 \mathrm{~Hz}, 1 \mathrm{H}, \mathrm{H}-2^{\prime}\right), 3.10-3.32\left(\mathrm{~m}, 3 \mathrm{H}, \mathrm{H}-1, \mathrm{H}-6^{\prime} \mathrm{b}, \mathrm{H}-6^{\prime} \mathrm{a}\right)$, 2.45 (ddd, $J=4.0$ and $12.8 \mathrm{~Hz} 1 \mathrm{H}, \mathrm{H}-2 \mathrm{eq}), 1.98$ (ddd, $J=12.8$ $\mathrm{Hz}, 1 \mathrm{H}, \mathrm{H}-2 \mathrm{ax}) .{ }^{13} \mathrm{C}$ NMR (100 MHz, CD $\left.3 \mathrm{OD}\right) \delta 132.0-137.0$ (6C-np), 127-130 (14CH-np), 93.9 (C-1' $), 84.7$ (C-5), 78.1 (C4'), 77.5 (C-4), 76.1 ( $\mathrm{CH}_{2}$-np), 75.1 (C-6 and $\mathrm{CH}_{2}$-np), 73.4 (C$\left.5^{\prime}\right), 69.2\left(\mathrm{C}-3^{\prime}\right), 54.38\left(\mathrm{C}-2^{\prime}\right), 51.8(\mathrm{C}-3), 50.7(\mathrm{C}-1), 41.0\left(\mathrm{C}-6^{\prime}\right)$, 29.7 (C-2). LRMS (DCI) $m / z: 603[\mathrm{M}+\mathrm{H}]^{+}, 463[\mathrm{M}+\mathrm{H}-$ $2 \mathrm{NM}]^{+}$; purity: $98 \%$ (HPLC).

6-Mono-O-[(2-naphthyl)methyl] neamine derivative 5: prepared according to the method previously used for the regioselective alkylation of neamine in the position $6 .{ }^{9}$ To a solution of $\mathbf{1 2}^{8}(502 \mathrm{mg})$ in $6 \mathrm{~mL}$ of DMF/THF $(1 / 1, \mathrm{v} / \mathrm{v})$ under argon was first added $\mathrm{NaH}(60 \%, 170 \mathrm{mg}, 10$ equiv) and after $15 \mathrm{~min}$ stirring at $\mathrm{rt}$ the $2-\mathrm{NMBr}(130 \mathrm{mg}, 5$ equiv). The resulting mixture was stirred for $4 \mathrm{~h}$ at $\mathrm{rt}$, and then DCM was added. The organic phase was washed with an ammonium chloride aqueous saturated solution, water, and then brine before being dried over $\mathrm{MgSO}_{4}$, filtrated, and concentrated under reduced pressure. The residue obtained was chromatographed on alumina gel with a gradient of DCM/methanol from 100/0 to 99.8 / 0.2 to give the protected compound in $12 \%$ yield. LRMS (MALDI, DHB) $m / z: 1454[\mathrm{M}+\mathrm{Na}]^{+}, 1430[\mathrm{M}+\mathrm{H}]^{+}, 1211$ $[\mathrm{M}-\mathrm{Tr}+\mathrm{Na}]^{+}, 1187[\mathrm{M}-\mathrm{Tr}+\mathrm{H}]^{+}$. Then procedure B was applied for obtaining 5: $82 \%$ yield. ${ }^{1} \mathrm{H}$ NMR $\left(400 \mathrm{MHz}, \mathrm{D}_{2} \mathrm{O}\right) \delta$ 7.86-7.91 (m, 2H, H-np), 7.48-7.53 (m, 2H, H-np), 5.89 (d, $J=$ $\left.3.6 \mathrm{~Hz}, 1 \mathrm{H}, \mathrm{H}-1^{\prime}\right), 5.04$ (d, $\left.J=11.2 \mathrm{~Hz}, 1 \mathrm{H}, \mathrm{CH}_{2}-\mathrm{np}\right), 4.88$ (d, $\left.J=11.2 \mathrm{~Hz}, 1 \mathrm{H}, \mathrm{CH}_{2}-\mathrm{np}\right), 3.88-3.98$ (m, 3H, H-3', H-5', H-4), $3.85(\mathrm{dd}, J=8.8$ and $9.2 \mathrm{~Hz}, 1 \mathrm{H}, \mathrm{H}-5), 3.30-3.49(\mathrm{~m}, 5 \mathrm{H}, \mathrm{H}-3$, H-4', H-2', H-6' b, H-1), 3.22 (dd, $J=6.8$ and $13.6 \mathrm{~Hz}, 1 \mathrm{H}, \mathrm{H}-$ $\left.6^{\prime} \mathrm{a}\right), 2.42$ (ddd, $J=4.0$ and $\left.12.4 \mathrm{~Hz}, 1 \mathrm{H}, \mathrm{H}-2 \mathrm{eq}\right), 1.83(\mathrm{ddd}, J=$ $12.4 \mathrm{~Hz}, 1 \mathrm{H}, \mathrm{H}-2 \mathrm{ax}) .{ }^{13} \mathrm{C} \mathrm{NMR}\left(100 \mathrm{MHz}, \mathrm{D}_{2} \mathrm{O}\right) \delta 134.4-132.9$ (3C-np), 128.6-126.4 (7CH-np), $96.0\left(\mathrm{C}^{\prime} 1^{\prime}\right), 79.9(\mathrm{C}-6), 77.5(\mathrm{C}-$ 4), $75.8(\mathrm{C}-5), 75.2\left(\mathrm{CH}_{2}-\mathrm{np}\right), 70.6\left(\mathrm{C}-4^{\prime}\right), 69.3\left(\mathrm{C}-5^{\prime}\right), 68.2\left(\mathrm{C}-3^{\prime}\right)$, $53.5\left(\mathrm{C}-2^{\prime}\right), 48.9(\mathrm{C}-1), 48.4(\mathrm{C}-3), 40.1\left(\mathrm{C}-6^{\prime}\right), 28.2$ (C-2). LRMS $\left(\mathrm{FAB}^{+}, \mathrm{NBA}\right) m / z: 463[\mathrm{M}+\mathrm{H}]^{+}, 303,161,141 . \mathrm{HRMS}_{\left(\mathrm{ESI}^{+}\right)}$ $m / z:[\mathrm{M}+\mathrm{H}]^{+}$calculated 463.2557 , found 463.2545 ; purity: 95\% (HPLC).

$3^{\prime}, 4^{\prime}$-Di- $O$-[(2-naphthyl)methyl] neamine derivative 6: prepared from 14a through the selective removal of the 2-NM group at the position 6 according to procedure $\mathrm{B}$ at $\mathrm{rt}$ during $3 \mathrm{~h}$. $51 \%$ yield. ${ }^{1} \mathrm{H}$ NMR $\left(400 \mathrm{MHz}, \mathrm{CD}_{3} \mathrm{OD}\right) \delta 7.30-7.85(\mathrm{~m}, 14 \mathrm{H}$, H-np), 6.03 (d, $\left.J=3.6 \mathrm{~Hz}, 1 \mathrm{H}, \mathrm{H}^{-1}\right)^{\prime}, 4.80-5.04$ (m, 4H, 2CH $2^{-}$ np), $4.30-4.40\left(\mathrm{~m}, 2 \mathrm{H}, \mathrm{H}-3^{\prime}, \mathrm{H}-5^{\prime}\right), 4.08(\mathrm{dd}, J=9.7 \mathrm{~Hz}, 1 \mathrm{H}, \mathrm{H}-$ 4), 3.58-3.67 (m, 3H, H-5, H-4', H-2'), 3.39-3.53 (m, 2H, H-6, $\mathrm{H}-3), 3.34\left(\mathrm{dd}, J=3.5\right.$ and $\left.13.5 \mathrm{~Hz}, 1 \mathrm{H}, \mathrm{H}-6^{\prime} \mathrm{b}\right), 3.21$ (ddd, $J=$ 4.2 and $12.5 \mathrm{~Hz}, 1 \mathrm{H}, \mathrm{H}-1), 3.10(\mathrm{dd}, J=9.8$ and $13.3 \mathrm{~Hz}, 1 \mathrm{H}, \mathrm{H}-$ $6^{\prime} \mathrm{a}$ ), 2.47 (ddd, $J=4.0$ and $\left.12.4 \mathrm{~Hz}, 1 \mathrm{H}, \mathrm{H}-2 \mathrm{eq}\right), 1.30$ (ddd, $J=$ $12.5 \mathrm{~Hz}, 1 \mathrm{H}, \mathrm{H}-2 \mathrm{ax}) .{ }^{13} \mathrm{C} \mathrm{NMR}\left(100 \mathrm{MHz}, \mathrm{D}_{2} \mathrm{O}\right) \delta 132.7-134.4$ (6C-np), 125.3-128.4 (14CH-np), $95.4\left(\mathrm{C}^{\prime} 1^{\prime}\right), 78.2\left(\mathrm{C}-4^{\prime}\right), 77.7$ (C-4), 75.7 (C-3'), 75.1 (C-5), 74.9 (2 $\mathrm{CH}_{2}$-np), 72.3 (C-6), 69.7 $\left(\mathrm{C}-5^{\prime}\right), 52.6\left(\mathrm{C}-2^{\prime}\right), 49.6(\mathrm{C}-1), 48.4(\mathrm{C}-3), 39.8\left(\mathrm{C}-6^{\prime}\right), 28.2(\mathrm{C}-2)$. LRMS $\left(\mathrm{ESI}^{+}\right) m / z: 603[\mathrm{M}+\mathrm{H}]^{+}, 463,441,301,141$. HRMS $\left(\mathrm{ESI}^{+}\right) \mathrm{m} / z:[\mathrm{M}+\mathrm{Na}]^{+}$calculated 625.3002, found 625.3024; purity: 96\% (HPLC). $3^{\prime}, 6-D i-(7 a-d)$ and $3^{\prime}, 4^{\prime}, 6$-Trialkylated $(10 a-d)$ Neamine Derivatives. $3^{\prime}, 6-\mathrm{Di}-O-(7 \mathbf{a})$ and $3^{\prime}, 4^{\prime}, 6$-tri- $O$-[(2-naphthyl)methyl] (10a) derivatives: 13a and 14a were prepared in $40 \%$ and $38 \%$ yields, respectively, according to procedure A from $12(2.0 \mathrm{~g})$, DMF/THF (1/9, $20 \mathrm{~mL}), \mathrm{NaH}$ (217 mg), 2NMBr (857 mg), and after chromatography with cyclohexane/DCM (50/50). 13a: LRMS $\left(\mathrm{FAB}^{+}\right.$, NBA) $m / z: 1594[\mathrm{M}+\mathrm{Na}]^{+}$. 14a: LRMS $\left(\mathrm{FAB}^{+}, \mathrm{NBA}\right) m / z: 1735[\mathrm{M}+\mathrm{Na}]^{+}$. 13a $(602 \mathrm{mg}, 0.39 \mathrm{mmol})$ and $14 \mathbf{a}(121 \mathrm{mg}, 0.07 \mathrm{mmol})$, respectively, were treated according to procedure B. 7a and 10a were isolated as chlorhydrate salts after ion exchange chromatography in 70 and $65 \%$ yields, respectively. HPLC analysis showed 94 and $96 \%$ purity for $7 \mathbf{a}$ and 10a, respectively. 7a: $70 \%$ yield. ${ }^{1} \mathrm{H}$ NMR $\left(400 \mathrm{MHz}, \mathrm{D}_{2} \mathrm{O}\right) \delta$ 7.84-7.89 (m, 8H, H-np), 7.47-7.50 (m, 6H, H-np), 5.86 (d, $J=$ $\left.3.6 \mathrm{~Hz}, 1 \mathrm{H}, \mathrm{H}_{-} \mathrm{1}^{\prime}\right), 5.05\left(\mathrm{~d}, J=12.0 \mathrm{~Hz}, 1 \mathrm{H}, \mathrm{CH}_{2}-\mathrm{np}\right), 5.02(\mathrm{~d}, J=$ $\left.12.0 \mathrm{~Hz}, 1 \mathrm{H}, \mathrm{CH}_{2}-\mathrm{np}\right), 4.88$ (d, $\left.J=12.0 \mathrm{~Hz}, 1 \mathrm{H}, \mathrm{CH}_{2}-\mathrm{np}\right), 4.85$ $\left(\mathrm{d}, J=12.0 \mathrm{~Hz}, 1 \mathrm{H}, \mathrm{CH}_{2}-\mathrm{np}\right), 4.04(\mathrm{dd}, J=8.5$ and $10.4 \mathrm{~Hz}, 1 \mathrm{H}$, H-3 $\left.3^{\prime}\right), 3.96\left(\mathrm{~m}, 1 \mathrm{H}, \mathrm{H}-5^{\prime}\right), 3.91$ (dd, $\left.J=10.0 \mathrm{~Hz}, 1 \mathrm{H}, \mathrm{H}-4\right), 3.82$ $(\mathrm{dd}, J=9.2 \mathrm{~Hz}, 1 \mathrm{H}, \mathrm{H}-5), 3.65\left(\mathrm{dd}, J=9.2 \mathrm{~Hz}, 1 \mathrm{H}, \mathrm{H}-4^{\prime}\right), 3.58$ $(\mathrm{dd}, J=9.2 \mathrm{~Hz}, 1 \mathrm{H}, \mathrm{H}-6), 3.45(\mathrm{dd}, J=3.6$ and $10.4 \mathrm{~Hz}, 1 \mathrm{H}, \mathrm{H}-$ $\left.2^{\prime}\right), 3.43-3.28$ (m, 3H, H-3, H-6' b, H-1), 3.22 (dd, $J=9.6$ and $\left.12.8 \mathrm{~Hz}, 1 \mathrm{H}, \mathrm{H}-6^{\prime} \mathrm{a}\right), 2.42$ (ddd, $J=4.0$ and $12.4 \mathrm{~Hz}, 1 \mathrm{H}, \mathrm{H}-2 \mathrm{eq}$ ), 2.01 (ddd, $J=12.4 \mathrm{~Hz}, 1 \mathrm{H}, \mathrm{H}-2 \mathrm{ax}) .{ }^{13} \mathrm{C} \mathrm{NMR}(100 \mathrm{MHz}$, $\left.\mathrm{CD}_{3} \mathrm{OD}\right) \delta 133.1-135.6$ (6C-np), 125.6-127.7 (14CH-np), 94.4 $\left(\mathrm{C}-1^{\prime}\right), 80.3$ (C-6), 76.6 (C-4), 75.9 and 75.8 (C-5 and C-3'), 74.9 (2 $\left.\mathrm{CH}_{2}-\mathrm{np}\right), 72.2\left(\mathrm{C}-4^{\prime}\right), 70.4\left(\mathrm{C}-5^{\prime}\right), 53.1\left(\mathrm{C}-2^{\prime}\right), 49.3(\mathrm{C}-1), 48.9$ (C-3), $40.4\left(\mathrm{C}^{\prime} 6^{\prime}\right), 28.3(\mathrm{C}-2)$. LRMS $\left(\mathrm{DCI}^{+}\right) \mathrm{m} / z: 603[\mathrm{M}+\mathrm{H}]^{+}$, 463, 303, 141. HRMS $\left(\mathrm{ESI}^{+}\right) \mathrm{m} / z:[\mathrm{M}+\mathrm{H}]^{+}$calculated 603.3183, found 603.3186, $[\mathrm{M}+\mathrm{Na}]^{+}$calculated 625.3002, found 625.3006; purity: 94\% (HPLC). 10a: $65 \%$ yield. ${ }^{1} \mathrm{H}$ NMR $(400 \mathrm{MHz}$, $\left.\mathrm{CD}_{3} \mathrm{OD}\right) \delta 7.39-7.97(\mathrm{~m}, 21 \mathrm{H}, \mathrm{H}-\mathrm{np}), 6.03(\mathrm{~d}, J=3.6 \mathrm{~Hz}, 1 \mathrm{H}$, $\left.\mathrm{H}^{-1}{ }^{\prime}\right), 4.94-5.29$ (m, 6H, $\left.\mathrm{CH}_{2}-\mathrm{np}\right), 3.57-3.59$ (m, 2H, H-3', $\left.\mathrm{H}-5^{\prime}\right), 4.20(\mathrm{dd}, J=9.6 \mathrm{~Hz}, 1 \mathrm{H}, \mathrm{H}-4), 4.08(\mathrm{dd}, J=9.2 \mathrm{~Hz}$, 1H, H-5), 3.65-3.74 (m, 2H, H-6, H-4'), 3.49-3.56 (m, 2H, H-3, $\left.\mathrm{H}-2^{\prime}\right), 3.35-3.42\left(\mathrm{~m}, 2 \mathrm{H}, \mathrm{H}-6^{\prime} \mathrm{b}, \mathrm{H}-1\right), 3.17$ (dd, $J=9.6$ and 13.2 Hz, 1H, H-6'a), 2.46 (ddd, $J=4.0$ and $12.4 \mathrm{~Hz}, 1 \mathrm{H}, \mathrm{H}-2 \mathrm{eq}$ ), 2.01 (ddd, $J=12.8 \mathrm{~Hz}, 1 \mathrm{H}, \mathrm{H}-2 \mathrm{ax}) .{ }^{13} \mathrm{C}$ NMR $\left(100 \mathrm{MHz}, \mathrm{CD}_{3} \mathrm{OD}\right) \delta$ 133.1-135.4 (9C-np), 125.3-127.9 (21CH-np), 95.2 (C-1'), 80.5 (C-6), 78.9 and 78.5 (C-4 and C-4' $), 77.5\left(\mathrm{C}-3^{\prime}\right), 76.3(\mathrm{C}-5), 74.7$ and $74.4\left(2 \mathrm{CH}_{2}-\mathrm{np}\right), 69.7\left(\mathrm{C}-5^{\prime}\right), 53.4\left(\mathrm{C}-2^{\prime}\right), 49.5(\mathrm{C}-1), 48.6$ (C-3), $40.3\left(\mathrm{C}-6^{\prime}\right), 29.5(\mathrm{C}-2)$. LRMS (DCI $\left.{ }^{+}\right) \mathrm{m} / z: 743[\mathrm{M}+\mathrm{H}]^{+}$, $603[\mathrm{M}+\mathrm{H}-2 \mathrm{NM}]^{+}, 441,303,141 . \mathrm{HRMS}\left(\mathrm{ESI}^{+}\right) \mathrm{m} / z:[\mathrm{M}+$ $\mathrm{H}]^{+}$calculated 743.3809 , found $743.3810,[\mathrm{M}+\mathrm{Na}]^{+}$calculated 765.3628, found 765.3628; purity: 96\% (HPLC).

$3^{\prime}, 6$-Di- $O$-benzyl (7b) and $3^{\prime}, 4^{\prime}, 6$-tri- $O$-benzyl (10b) derivatives: 13b and 14b were obtained respectively in $35 \%$ and $45 \%$ yields according to procedure A with DMF/THF $(1 / 9, v / v)$ as solvents and benzyl bromide as alkylating agent. After deprotection, the trifluoroacetate salts of $\mathbf{7 b}$ and $\mathbf{1 0 b}$ were converted to the chlorydrate salts as $7 \mathbf{a}$ and 10a. $7 \mathbf{b}$ : $98 \%$ yield. ${ }^{1} \mathrm{H}$ NMR (400 $\left.\mathrm{MHz}, \mathrm{D}_{2} \mathrm{O}\right) \delta 7.30-7.40(\mathrm{~m}, 10 \mathrm{H}, \mathrm{H}-\mathrm{Bn}), 5.86(\mathrm{~d}, J=3.6 \mathrm{~Hz}$, $\left.1 \mathrm{H}, \mathrm{H}-1^{\prime}\right), 4.89\left(\mathrm{~d}, J=11.0 \mathrm{~Hz}, 1 \mathrm{H}, \mathrm{CH}_{2}-\mathrm{Bn}\right), 4.87(\mathrm{~d}, J=11.0$ $\left.\mathrm{Hz}, 1 \mathrm{H}, \mathrm{CH}_{2}-\mathrm{Bn}\right), 4.65-4.73\left(\mathrm{~m}, 2 \mathrm{H}, \mathrm{CH}_{2}-\mathrm{Bn}\right), 4.00(\mathrm{dd}, J=8.8$ and $\left.10.4 \mathrm{~Hz}, 1 \mathrm{H}, \mathrm{H}-3^{\prime}\right), 3.91-3.98\left(\mathrm{~m}, 2 \mathrm{H}, \mathrm{H}-5^{\prime}, \mathrm{H}-4\right), 3.81(\mathrm{dd}$, $J=9.2 \mathrm{~Hz}, 1 \mathrm{H}, \mathrm{H}-5), 3.61\left(\mathrm{dd}, J=9.2 \mathrm{~Hz}, 1 \mathrm{H}, \mathrm{H}-4^{\prime}\right), 3.57(\mathrm{dd}$, $J=9.2$ and $10.4 \mathrm{~Hz}, 1 \mathrm{H}, \mathrm{H}-6), 3.35-3.46$ (m, 3H, H-2', H-6' $\mathrm{b}$, $\mathrm{H}-3), 3.29(\mathrm{~m}, 1 \mathrm{H}, \mathrm{H}-1), 3.21(\mathrm{dd}, J=7.2$ and $13.6 \mathrm{~Hz}, 1 \mathrm{H}$, H-6'a), 2.39 (ddd, $J=4.4$ and $12.4 \mathrm{~Hz}, 1 \mathrm{H}, \mathrm{H}-2 \mathrm{eq}$ ), 1.80 (ddd, $J=12.4 \mathrm{~Hz}, 1 \mathrm{H}, \mathrm{H}-2 \mathrm{ax}) .{ }^{13} \mathrm{C}$ NMR $\left(100 \mathrm{MHz}, \mathrm{D}_{2} \mathrm{O}\right) \delta 137.0$ and 136.7 (2C-Bn), 128.7-128.9 (10CH-Bn), $95.7\left({\left.\mathrm{C}-1^{\prime}\right), 79.8}^{\prime}\right.$ (C-6), 77.3 (C-4), 75.7 (C-5 and C-3'), 75.1 and $75.2\left(2 \mathrm{CH}_{2}-\mathrm{Bn}\right)$, $71.0\left(\mathrm{C}-4^{\prime}\right), 69.8\left(\mathrm{C}-5^{\prime}\right), 52.6\left(\mathrm{C}-2^{\prime}\right), 48.8(\mathrm{C}-1), 48.4(\mathrm{C}-3), 39.9$ $\left(\mathrm{C}^{-6}{ }^{\prime}\right), 28.2(\mathrm{C}-2)$. LRMS $\left(\mathrm{DCI}^{+}\right) m / z: 503\left[\mathrm{M}+\mathrm{H}^{+}, 295,253\right.$. HRMS $\left(\mathrm{ESI}^{+}\right) m / z$ : $[\mathrm{M}+\mathrm{H}]^{+}$calculated 503.2870, found 503.2871, $[\mathrm{M}+\mathrm{Na}]^{+}$525.2689, found 525.2689, $[\mathrm{M}+\mathrm{K}]^{+}$ calculated 541.2428, found 541.2451; purity: 99\% (HPLC). 10b: $99 \%$ yield. ${ }^{1} \mathrm{H}$ NMR $\left(400 \mathrm{MHz}, \mathrm{CD}_{3} \mathrm{OD}\right) \delta 7.31-7.49(\mathrm{~m}, 15 \mathrm{H}$, $\mathrm{H}-\mathrm{Bn}), 6.11\left(\mathrm{~d}, J=3.6 \mathrm{~Hz}, 1 \mathrm{H}, \mathrm{H}^{-1}{ }^{\prime}\right), 5.11(\mathrm{~d}, J=10.9 \mathrm{~Hz}, 1 \mathrm{H}$, $\left.\mathrm{CH}_{2}-\mathrm{Bn}\right), 4.98$ (d, $\left.J=11.3 \mathrm{~Hz}, 1 \mathrm{H}, \mathrm{CH}_{2}-\mathrm{Bn}\right), 4.93$ (d, $J=11.3$ $\left.\mathrm{Hz}, 1 \mathrm{H}, \mathrm{CH}_{2}-\mathrm{Bn}\right), 4.82\left(\mathrm{~m}, 2 \mathrm{H}, \mathrm{CH}_{2}-\mathrm{Bn}\right), 4.71(\mathrm{~d}, J=11.3 \mathrm{~Hz}$, 
$1 \mathrm{H}, \mathrm{CH}_{2}-\mathrm{Bn}$ ), 4.32-4.44 (m, 3H, H-3', H-5', H-4), 3.98 (dd, $J=$ $9.2 \mathrm{~Hz}, 1 \mathrm{H}, \mathrm{H}-5$ ), 3.67 (dd, $J=10.0 \mathrm{~Hz}, 1 \mathrm{H}, \mathrm{H}-6), 3.55-3.63$ (m, 3H, H-3, H-2', H-4'), 3.34-3.42 (m, 2H, H-6' b, H-1), 3.19 (dd, $J=9.8$ and $\left.13.3 \mathrm{~Hz}, 1 \mathrm{H}, \mathrm{H}-6^{\prime} \mathrm{a}\right), 2.48(\mathrm{ddd}, J=4.4$ and 12.3 $\mathrm{Hz}, 1 \mathrm{H}, \mathrm{H}-2 \mathrm{eq}), 2.09$ (ddd, $J=12.4 \mathrm{~Hz}, 1 \mathrm{H}, \mathrm{H}-2 \mathrm{ax}) .{ }^{13} \mathrm{C} \mathrm{NMR}$ (100 MHz, CD 3 OD) $\delta 137.3$ and 137.2 (3C-Bn), 127.4-128.2

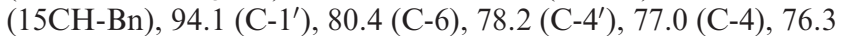
(C-5), $76.1\left(\mathrm{C}-3^{\prime}\right), 74.8,74.5$, and $74.42\left(\mathrm{CH}_{2}-\mathrm{Bn}\right), 70.1\left(\mathrm{C}-5^{\prime}\right)$, $52.7\left(\mathrm{C}-2^{\prime}\right), 49.3(\mathrm{C}-1), 48.7$ (C-3), $40.0\left(\mathrm{C}-6^{\prime}\right), 28.6(\mathrm{C}-2)$. LRMS $\left(\mathrm{DCI}^{+}\right) m / z: 593[\mathrm{M}+\mathrm{H}]^{+}, 341,253 . \mathrm{HRMS}\left(\mathrm{ESI}^{+}\right) m / z:[\mathrm{M}+$ $\mathrm{H}]^{+}$calculated 593.3339, found 593.3341, $[\mathrm{M}+\mathrm{Na}]^{+}$calculated 615.3158, found 615.3154; purity: 99\% (HPLC).

$3^{\prime}, 6$-Di- $O$-[(2-pyridyl)methyl] (7c) and $3^{\prime}, 4^{\prime}, 6$-tri- $O$-[(2-pyridyl)methyl] (10c) neamine derivatives: prepared as 7a and 10a using 2-(chloromethyl)pyridine (free base) as alkylating agent and DMF/THF $(1 / 9, \mathrm{v} / \mathrm{v})$ as solvents. The intermediate protected compounds $\mathbf{1 3} \mathbf{c}$ and $\mathbf{1 4} \mathbf{c}$ were obtained with $30 \%$ and $15 \%$ yields respectively after chromatography with a gradient of cyclohexane/DCM from 50/50 to 20/80. 13c: LRMS (MALDI, DHB) $m / z: 1497[\mathrm{M}+\mathrm{Na}]^{+}, 1475[\mathrm{M}+\mathrm{H}]^{+}, 1255[\mathrm{M}-\mathrm{Tr}+$ $\mathrm{Na}]^{+}, 1231[\mathrm{M}-\mathrm{Tr}+\mathrm{H}]^{+}$. 14c: LRMS (MALDI, DHB) $m / z$ : $1588[\mathrm{M}+\mathrm{Na}]^{+}, 1566[\mathrm{M}+\mathrm{H}]^{+}, 1346[\mathrm{M}-\mathrm{Tr}+\mathrm{Na}]^{+}, 1323$ $[\mathrm{M}-\mathrm{Tr}+\mathrm{H}]^{+} . \mathbf{1 3 c}$ and $\mathbf{1 4 c}$ then were treated according to procedure $\mathrm{B}$ for obtaining $\mathbf{7 c}$ and $\mathbf{1 0 c}$, respectively. $7 \mathbf{c}$ : $80 \%$ yield. ${ }^{1} \mathrm{H}$ NMR $\left(400 \mathrm{MHz}, \mathrm{D}_{2} \mathrm{O}\right) \delta 8.44(\mathrm{~d}, J=4.8 \mathrm{~Hz}, 1 \mathrm{H}$, H-py), 8.30 (m, 2H, H-py), 7.85 (m, 1H, H-py), 7.74 (m, 1H, Hpy), 7.23-7.41 (m, 7H, H-py), 5.88 (d, $\left.J=4.0 \mathrm{~Hz}, 1 \mathrm{H}, \mathrm{H}-1^{\prime}\right)$, $4.98\left(\mathrm{~d}, J=13.6 \mathrm{~Hz}, 1 \mathrm{H}, \mathrm{CH}_{2}\right.$-py), $4.86(\mathrm{~d}, J=13.2 \mathrm{~Hz}, 1 \mathrm{H}$, $\mathrm{CH}_{2}$-py), 4.65-4.81 (m, 4H, $\mathrm{CH}_{2}$-py), 4.22 (dd, $J=8.4$ and 10.0 $\left.\mathrm{Hz}, 1 \mathrm{H}, \mathrm{H}-3^{\prime}\right), 4.11\left(\mathrm{ddd}, J=3.2\right.$ and $\left.8.4 \mathrm{~Hz}, 1 \mathrm{H}, \mathrm{H}-5^{\prime}\right), 3.91(\mathrm{dd}$, $J=9.6 \mathrm{~Hz}, 1 \mathrm{H}, \mathrm{H}-4), 3.85(\mathrm{dd}, J=8.8$ and $9.2 \mathrm{~Hz}, 1 \mathrm{H}, \mathrm{H}-5)$, $3.66\left(\mathrm{dd}, J=8.8 \mathrm{~Hz}, 1 \mathrm{H}, \mathrm{H}-4^{\prime}\right), 3.63(\mathrm{dd}, J=9.2$ and $10.0 \mathrm{~Hz}$, $1 \mathrm{H}, \mathrm{H}-6), 3.57\left(\mathrm{dd}, J=3.6\right.$ and $\left.10.4 \mathrm{~Hz}, 1 \mathrm{H}, \mathrm{H}-2^{\prime}\right), 3.28-3.46$ (m, 3H, H-3, H-1, H-6'), $3.16(\mathrm{dd}, J=8.4$ and $13.2 \mathrm{~Hz}, 1 \mathrm{H}, \mathrm{H}-$ $\left.6^{\prime} \mathrm{a}\right), 2.42$ (ddd, $J=4.0$ and $\left.8.4 \mathrm{~Hz}, 1 \mathrm{H}, \mathrm{H}-2 \mathrm{eq}\right), 1.82(\mathrm{ddd}, J=$ $8.4 \mathrm{~Hz}, 1 \mathrm{H}, \mathrm{H}-2 \mathrm{ax}) .{ }^{13} \mathrm{C} \mathrm{NMR}\left(100 \mathrm{MHz}, \mathrm{D}_{2} \mathrm{O}\right) \delta 154.9-154.6$ (3C-py), 147.4-122.7 (12CH-py), $95.6\left(\mathrm{C}^{\prime} 1^{\prime}\right), 81.9$ (C-6), 79.0 $\left(\mathrm{C}-4^{\prime}\right), 77.5$ and $77.0\left(\mathrm{C}-4\right.$ and $\left.\mathrm{C}-3^{\prime}\right), 75.3(\mathrm{C}-5), 74.0$ and 73.5 (2 $\mathrm{CH}_{2}$-py), 69.1 (C-5'), 52.7 (C-2'), 48.9 (C-1), 48.3 (C-3), 39.9 $\left(\mathrm{C}-6^{\prime}\right), 28.4(\mathrm{C}-2)$. LRMS $\left(\mathrm{ESI}^{+}\right) m / z: 618[\mathrm{M}+\mathrm{Na}]^{+}, 596[\mathrm{M}+$ $\mathrm{H}]{ }^{+}, 345,254$. HRMS $\left(\mathrm{ESI}^{+}\right) m / z:[\mathrm{M}+\mathrm{H}]^{+}$calculated 596.3197, found 596.3183, $[\mathrm{M}+\mathrm{Na}]^{+}$calculated 618.3016, found 618.3028; purity: $99 \%$ (HPLC). 10c: $20 \%$ yield. ${ }^{1} \mathrm{H}$ NMR $\left(400 \mathrm{MHz}, \mathrm{D}_{2} \mathrm{O}\right) \delta 8.62(\mathrm{dd}, J=1.2$ and $6.4 \mathrm{~Hz}, 2 \mathrm{H}$, H-py), 8.43 (ddd, $J=1.2$ and $8.0 \mathrm{~Hz}, 2 \mathrm{H}, \mathrm{H}-\mathrm{py}$ ), 7.83-7.89 (m, 4H, H-py), 5.89 (d, $J=3.6 \mathrm{~Hz}, 1 \mathrm{H}, \mathrm{H}^{\prime}{ }^{\prime}$ ), 5.30 (d, $J=15.2$ $\mathrm{Hz}, 2 \mathrm{H}, \mathrm{CH}_{2}$-py), 5.18 (d, $J=14.0 \mathrm{~Hz}, 1 \mathrm{H}, \mathrm{CH}_{2}$-py), 5.13 (d, $J=14.8 \mathrm{~Hz}, 1 \mathrm{H}, \mathrm{CH}_{2}$-py), $4.15(\mathrm{dd}, J=8.8$ and $10.8 \mathrm{~Hz}, 1 \mathrm{H}$, H-3') $3.89-4.01$ ( $\left.m, 3 \mathrm{H}, \mathrm{H}-5^{\prime}, \mathrm{H}-4, \mathrm{H}-5\right), 3.76$ (dd, $J=8.8$ and $10.0 \mathrm{~Hz}, 1 \mathrm{H}, \mathrm{H}-6), 3.68\left(\mathrm{dd}, J=8.8\right.$ and $\left.9.6 \mathrm{~Hz}, 1 \mathrm{H}, \mathrm{H}-4^{\prime}\right), 3.60$ $\left(\mathrm{dd}, J=3.6\right.$ and $\left.10.8 \mathrm{~Hz}, 1 \mathrm{H}, \mathrm{H}-2^{\prime}\right), 3.45-3.54(\mathrm{~m}, 2 \mathrm{H}, \mathrm{H}-3$, $\mathrm{H}-1), 3.37$ (dd, $J=2.4$ and $\left.13.6 \mathrm{~Hz}, 1 \mathrm{H}, \mathrm{H}-6^{\prime} \mathrm{b}\right), 3.18(\mathrm{dd}, J=$ 6.8 and $\left.13.6 \mathrm{~Hz}, 1 \mathrm{H}, \mathrm{H}-6^{\prime} \mathrm{a}\right), 2.48(\mathrm{ddd}, J=4.0$ and $12.8 \mathrm{~Hz}, 1 \mathrm{H}$, $\mathrm{H}-2 \mathrm{eq}), 1.90$ (ddd, $J=12.8 \mathrm{~Hz}, 1 \mathrm{H}, \mathrm{H}-2 \mathrm{ax}) .{ }^{13} \mathrm{C}$ NMR $(100$ $\left.\mathrm{MHz}, \mathrm{D}_{2} \mathrm{O}\right) \delta 152.0$ and 151.8 (C-py), 146.5-124.8 (8CH-py), $95.9\left(\mathrm{C}-1^{\prime}\right), 81.3(\mathrm{C}-6), 77.3\left(\mathrm{C}-4\right.$ et $\left.\mathrm{C}-3^{\prime}\right), 75.4(\mathrm{C}-5), 70.8\left(\mathrm{C}-4^{\prime}\right)$, $70.0\left(2 \mathrm{CH}_{2}\right.$-py), $69.5\left(\mathrm{C}-5^{\prime}\right), 52.4\left(\mathrm{C}-2^{\prime}\right), 48.6(\mathrm{C}-1), 48.2(\mathrm{C}-3)$, $39.8\left(\mathrm{C}^{\prime} 6^{\prime}\right), 28.2(\mathrm{C}-2)$. LRMS (FAB $\left.{ }^{+}, \mathrm{NBA}\right) m / z: 506[\mathrm{M}+$ $\mathrm{H}]^{+}, 414,381,254 . \mathrm{HRMS}\left(\mathrm{ESI}^{+}\right) \mathrm{m} / z:[\mathrm{M}+\mathrm{H}]^{+}$calculated 505.2775 , found $505.2769,[\mathrm{M}+\mathrm{Na}]^{+}$calculated 527.2594, found 527.2589; purity: 85\% (HPLC).

$3^{\prime}, 6-\mathrm{Di}-O$-[(2-quinolyl)methyl] (7d) and $3^{\prime}, 4^{\prime}, 6$-tri- $O$-[(2quinolyl)methyl] (10d) neamine derivatives: prepared as $\mathbf{7 a}$ and 10a using 2-(chloromethyl)quinoline (free base) as alkylating agent and DMF/THF $(1 / 9, \mathrm{v} / \mathrm{v})$ as solvents. The protected compounds 13d and $\mathbf{1 4 d}$ were obtained with $52 \%$ and $11 \%$ yields, respectively, after chromatography with a gradient of cyclohexane/DCM from 50/50 to 30/70. 13d: LRMS (MALDI, DHB) $m / z: 1596[\mathrm{M}+\mathrm{Na}]^{+}, 1574[\mathrm{M}+\mathrm{H}]^{+}, 1353[\mathrm{M}-\mathrm{Tr}+$ $\mathrm{Na}]^{+}, 1331[\mathrm{M}-\mathrm{Tr}+\mathrm{H}]^{+}$. 14d: LRMS (MALDI, DHB) $m / z: 1738[\mathrm{M}+\mathrm{Na}]^{+}, 1716[\mathrm{M}+\mathrm{H}]^{+}, 1496[\mathrm{M}-\mathrm{Tr}+\mathrm{Na}]^{+}$, $1472[\mathrm{M}-\mathrm{Tr}+\mathrm{H}]^{+}$. 13d and $\mathbf{1 4 d}$ then were treated according to procedure $\mathrm{B}$ for obtaining $\mathbf{7 d}$ and $\mathbf{1 0 d}$, respectively. 7d: $82 \%$ yield. ${ }^{1} \mathrm{H}$ NMR $\left(400 \mathrm{MHz}, \mathrm{D}_{2} \mathrm{O}\right) \delta 8.67(\mathrm{~d}, J=8.4 \mathrm{~Hz}, 1 \mathrm{H}, \mathrm{H}-$ qui), 8.60 (d, $J=8.8 \mathrm{~Hz}, 1 \mathrm{H}, \mathrm{H}$-qui), $7.66-8.06$ (m, 9H, H-qui), $7.63\left(\mathrm{~d}, J=8.4 \mathrm{~Hz}, 1 \mathrm{H}, \mathrm{H}\right.$-qui), $5.93\left(\mathrm{~d}, J=3.6 \mathrm{~Hz}, 1 \mathrm{H}, \mathrm{H}-1^{\prime}\right)$, $5.37\left(\mathrm{~d}, J=15.2 \mathrm{~Hz}, 1 \mathrm{H}, \mathrm{CH}_{2}\right.$-qui), $5.33(\mathrm{~d}, J=15.2 \mathrm{~Hz}, 1 \mathrm{H}$, $\mathrm{CH}_{2}$-qui), 5.25 (d, $J=15.2 \mathrm{~Hz}, 1 \mathrm{H}, \mathrm{CH}_{2}$-qui), $5.21(\mathrm{~d}, J=15.2$ $\mathrm{Hz}, 1 \mathrm{H}, \mathrm{CH}_{2}$-qui), 4.17 (dd, $J=8.8$ and $10.8 \mathrm{~Hz}, 1 \mathrm{H}, \mathrm{H}-3^{\prime}$ ), 3.92-4.03 (m, 3H, H-5', H-4, H-5), 3.76 (dd, $J=8.8$ and 10.4 $\mathrm{Hz}, 1 \mathrm{H}, \mathrm{H}-6), 3.72\left(\mathrm{dd}, J=8.8 \mathrm{~Hz}, 1 \mathrm{H}, \mathrm{H}-4^{\prime}\right), 3.64(\mathrm{dd}, J=3.6$ and $\left.10.8 \mathrm{~Hz}, 1 \mathrm{H}, \mathrm{H}-2^{\prime}\right), 3.46-3.57$ (m, 2H, H-3, H-1), 3.38 (dd, $J=3.6$ and $\left.13.6 \mathrm{~Hz}, 1 \mathrm{H}, \mathrm{H}-6^{\prime} \mathrm{b}\right), 3.20(\mathrm{dd}, J=6.8$ and $13.6 \mathrm{~Hz}$, $1 \mathrm{H}, \mathrm{H}-6^{\prime} \mathrm{a}$ ), 2.50 (ddd, $J=4.4$ and $12.8 \mathrm{~Hz}, 1 \mathrm{H}, \mathrm{H}-2 \mathrm{eq}$ ), 1.89 (ddd, $J=12.8 \mathrm{~Hz}, 1 \mathrm{H}, \mathrm{H}-2 \mathrm{ax}) .{ }^{13} \mathrm{C}$ NMR $\left(100 \mathrm{MHz}, \mathrm{D}_{2} \mathrm{O}\right) \delta$ 156.4-127.9 (6C-qui), 143.6-119.7 (12CH-qui), 96.1 (C-1'), 81.9 (C-6), 77.7 and $77.6\left(\mathrm{C}-4\right.$ and $\left.\mathrm{C}-3^{\prime}\right), 75.4(\mathrm{C}-5), 72.6$ and $72.2\left(2 \mathrm{CH}_{2}\right.$-qui), $70.8\left(\mathrm{C}-4^{\prime}\right), 69.5\left(\mathrm{C}-5^{\prime}\right), 52.6\left(\mathrm{C}-2^{\prime}\right), 48.8(\mathrm{C}-1)$, 48.3 (C-3), 39.8 (C-6'), 28.3 (C-2). LRMS (FAB ${ }^{+}$, NBA) $m / z$ : $605[\mathrm{M}+\mathrm{H}]^{+}$. HRMS $\left(\mathrm{ESI}^{+}\right) \mathrm{m} / z:[\mathrm{M}+\mathrm{H}]^{+}$calculated 605.3088, found 605.3092; purity: $94 \%$ (HPLC). 10d: $34 \%$ yield. ${ }^{1} \mathrm{H}$ NMR (400 MHz, $\left.\mathrm{D}_{2} \mathrm{O}\right) \delta 8.34(\mathrm{~d}, J=8.4 \mathrm{~Hz}, 1 \mathrm{H}, \mathrm{H}$-qui), $7.10-7.92\left(\mathrm{~m}, 17 \mathrm{H}, \mathrm{H}\right.$-qui), $5.95\left(\mathrm{~d}, J=3.2 \mathrm{~Hz}, 1 \mathrm{H}, \mathrm{H}-1^{\prime}\right), 5.19$ (d, $J=14.4 \mathrm{~Hz}, 1 \mathrm{H}, \mathrm{CH}_{2}$-qui), 5.08 (d, $J=14.8 \mathrm{~Hz}, 1 \mathrm{H}, \mathrm{CH}_{2^{-}}$ qui), 4.96 (d, $J=15.2 \mathrm{~Hz}, 1 \mathrm{H}, \mathrm{CH}_{2}$-qui), 4.89 (d, $J=14.0 \mathrm{~Hz}$, $1 \mathrm{H}, \mathrm{CH}_{2}$-qui), 4.70 (d, $J=14.8 \mathrm{~Hz}, 1 \mathrm{H}, \mathrm{CH}_{2}$-qui), 4.52 (d, $J=$ $14.4 \mathrm{~Hz}, 1 \mathrm{H}, \mathrm{CH}_{2}$-qui), $4.29\left(\mathrm{dd}, J=9.2\right.$ and $\left.10.0 \mathrm{~Hz}, 1 \mathrm{H}, \mathrm{H}-3^{\prime}\right)$, $4.20\left(\mathrm{ddd}, J=2.4\right.$ and $\left.8.4 \mathrm{~Hz}, 1 \mathrm{H}, \mathrm{H}-5^{\prime}\right), 3.98(\mathrm{dd}, J=9.2$ and $10.0 \mathrm{~Hz}, 1 \mathrm{H}, \mathrm{H}-4), 3.93(\mathrm{dd}, J=9.2 \mathrm{~Hz}, 1 \mathrm{H}, \mathrm{H}-5), 3.77$ (dd, $J=$ $9.2 \mathrm{~Hz}, 1 \mathrm{H}, \mathrm{H}-4^{\prime}$ ), 3.70 (dd, $J=9.2$ and $\left.10.0 \mathrm{~Hz}, 1 \mathrm{H}, \mathrm{H}-6\right), 3.65$ $\left(\mathrm{dd}, J=3.2\right.$ and $\left.10.4 \mathrm{~Hz}, 1 \mathrm{H}, \mathrm{H}-2^{\prime}\right), 3.47-3.55(\mathrm{~m}, 2 \mathrm{H}, \mathrm{H}-3$, $\mathrm{H}-1), 3.44\left(\mathrm{dd}, J=2.8\right.$ and $\left.13.6 \mathrm{~Hz}, 1 \mathrm{H}, \mathrm{H}-6^{\prime} \mathrm{b}\right), 3.28(\mathrm{dd}, J=$ 8.4 and $13.6 \mathrm{~Hz}, 1 \mathrm{H}, \mathrm{H}-6^{\prime} \mathrm{a}$ ), 2.48 (ddd, $J=4.0$ and $12.8 \mathrm{~Hz}, 1 \mathrm{H}$, $\mathrm{H}-2 \mathrm{eq}), 1.88$ (ddd, $J=12.8 \mathrm{~Hz}, 1 \mathrm{H}, \mathrm{H}-2 \mathrm{ax}) .{ }^{13} \mathrm{C} \mathrm{NMR}(100$ $\left.\mathrm{MHz}, \mathrm{D}_{2} \mathrm{O}\right) \delta 157.1-142.7$ (9C-qui), 140.5-118.5 (18CH-qui), $95.9\left(\mathrm{C}-1^{\prime}\right), 82.1(\mathrm{C}-6), 80.1\left(\mathrm{C}-4^{\prime}\right), 77.5$ and $77.1\left(\mathrm{C}-4\right.$ and $\left.\mathrm{C}-3^{\prime}\right)$, 75.5 (C-5), 73.7 ( $\mathrm{CH}_{2}$-qui), 69.3 (C-5'), 53.0 (C-2'), 49.0 (C-1), 48.4 (C-3), $40.0\left({\mathrm{C}-6^{\prime}}^{\prime}\right), 28.4(\mathrm{C}-2)$. LRMS (FAB $\left.{ }^{+}, \mathrm{NBA}\right) \mathrm{m} / z$ : $747[\mathrm{M}+\mathrm{H}]^{+}$. HRMS $\left(\mathrm{ESI}^{+}\right) \mathrm{m} / z:[\mathrm{M}+\mathrm{H}]^{+}$calculated 748.3714, found 748.3743, $\left[\mathrm{M}+\mathrm{Na}^{+}\right.$calculated 770.3534 , found 770.3563; purity: $90 \%$ (HPLC).

4',6-Di-O-[(2-naphthyl)methyl] neamine derivative 9: 12 ( $1 \mathrm{~g}$, 1 equiv, $0.76 \mathrm{mmol}$ ) was dissolved in $25 \mathrm{~mL}$ of anhydrous toluene under argon. $\mathrm{NaH}(60 \%, 125 \mathrm{mg}, 4$ equiv, $3.12 \mathrm{mmol})$ was added to the solution and then, after 15 min stirring, p-methoxybenzylchoride $(0.5 \mathrm{~mL}, 4$ equiv, $2.76 \mathrm{mmol})$ was added. Twenty-two days later, the reaction was stopped in adding ethanol and the reaction mixture was diluted with ethyl acetate. The organic layer was washed with water, $\mathrm{Na}_{2} \mathrm{SO}_{3}$, brine, and dried over $\mathrm{MgSO}_{4}$. The solvent was removed under reduce pressure, and the residue was chromatographed on alumina gel with a gradient of cyclohexane to toluene to ethyl acetate. The $N$-tetratritylated- $3^{\prime}$-monoPMB neamine derivative was obtained in 55\% yield. LRMS (MALDI, DHB) $m / z$ : $1435[\mathrm{M}+\mathrm{Na}]^{+}, 1412[\mathrm{M}+\mathrm{H}]^{+}, 1169[\mathrm{M}-\mathrm{Tr}+\mathrm{H}]^{+}, 927[\mathrm{M}-$ $2 \mathrm{Tr}+\mathrm{H}]^{+}$.

Under anhydrous conditions, $\mathrm{NaH}(60 \%, 33 \mathrm{mg}, 3$ equiv, $0.83 \mathrm{mmol}$ ) was added to a solution of this compound $(390 \mathrm{mg}$, 1 equiv, $0.28 \mathrm{mmol}$ ) in $15 \mathrm{~mL}$ of DMF. The mixture was stirred for $15 \mathrm{~min}$ at $0{ }^{\circ} \mathrm{C}$ in an ice bath, and then $2 \mathrm{NMBr}(152 \mathrm{mg}, 2.5$ equiv, $0.69 \mathrm{mmol}$ ) was added. The mixture was stirred for $30 \mathrm{~min}$ at $0{ }^{\circ} \mathrm{C}$ and then overnight at $\mathrm{rt}$. Another portion of $2 \mathrm{NMBr}(152$ $\mathrm{mg}$ ) was added, and the mixture was stirred for $12 \mathrm{~h}$ more. The completion of the reaction was monitored by TLC (toluene/ ethyl acetate: 9/1). The solvent of the mixture was evaporated under reduced pressure. The crude product was dissolved in ethyl acetate and washed twice with water and brine. The organic layer was dried over $\mathrm{MgSO}_{4}$ and concentrated under reduced pressure. The product was directly treated according to procedure B for obtaining 9 as a trifluoroacetic acid salt: $15 \%$ 
yield. ${ }^{1} \mathrm{H}$ NMR (400 MHz, $\left.\mathrm{D}_{2} \mathrm{O}\right) \delta 7.90-7.50$ (m, 14H, H-np), $6.01\left(\mathrm{~d}, J=3.6 \mathrm{~Hz}, 1 \mathrm{H}, \mathrm{H}-1^{\prime}\right), 5.20\left(\mathrm{~m}, 2 \mathrm{H}, \mathrm{CH}_{2}-\mathrm{np}\right), 4.90$ (m, 2H, $\left.\mathrm{CH}_{2}-\mathrm{np}\right), 4.27$ (dd, $J=8$ and $\left.12 \mathrm{~Hz}, 1 \mathrm{H}, \mathrm{H}-3^{\prime}\right), 4.18$ $\left(\mathrm{m}, 1 \mathrm{H}, \mathrm{H}-5^{\prime}\right), 4.11(\mathrm{dd}, J=10 \mathrm{~Hz}, 1 \mathrm{H}, \mathrm{H}-4), 3.91(\mathrm{dd}, J=10$ $\mathrm{Hz}, 1 \mathrm{H}, \mathrm{H}-5), 3.64$ (dd, $J=8 \mathrm{~Hz}, 1 \mathrm{H}, \mathrm{H}-6), 3.28-3.46$ (m, 5H, $\mathrm{H}-1, \mathrm{H}-3, \mathrm{H}-2^{\prime}, \mathrm{H}-4^{\prime}, \mathrm{H}-6^{\prime} \mathrm{b}$ ), 2.98 (dd, $J=8$ and $12 \mathrm{~Hz}, 1 \mathrm{H}$, H-6'a), 2.50 (m, 1H, H-2b), 2.08 (m, 1H, H-2a). ${ }^{13} \mathrm{C}$ NMR (100 $\left.\mathrm{MHz}, \mathrm{D}_{2} \mathrm{O}\right) \delta 132.0-135.0$ (6C-np), 129.9-127.3 (14CH-np), $97.2\left(\mathrm{C}-1^{\prime}\right), 82.0$ (C-6), 80.5 (C-4'), 79.5 (C-4), 78.0 (C-5), 76.4 $\left(\mathrm{CH}_{2}-\mathrm{np}\right), 76.1\left(\mathrm{CH}_{2}-\mathrm{np}\right), 70.6\left(\mathrm{C}-3^{\prime}\right), 70.3\left(\mathrm{C}-5^{\prime}\right), 55.6\left(\mathrm{C}-2^{\prime}\right)$, 50.8 (C-1), 50,2 (C-3), 42.1 (C-6'), 30.0 (C-2). HRMS (ESI $\left.{ }^{+}\right)$ $m / z:[\mathrm{M}+\mathrm{H}]^{+}$calculated 603.3183 , found $603.3199,[\mathrm{M}+$ $\mathrm{Na}]^{+}$calculated 625.3002, found 625.3005, $[\mathrm{M}+\mathrm{K}]^{+}$calculated 641.2741 , found 641.2726

$3^{\prime}, 4^{\prime}, 5,6$-Tetra- $O$-[(2-naphthyl)methyl] neamine derivative 11: prepared according to procedure A from $300 \mathrm{mg}$ of $\mathbf{1 2}$ in 7 $\mathrm{mL}$ of DMF using a large excess of $\mathrm{NaH}$ (10 equiv) and $2 \mathrm{NMBr}$ (7 equiv). The protected derivative was obtained in $66 \%$ yield. LRMS (MALDI, DHB) $m / z: 1874[\mathrm{M}+\mathrm{Na}]^{+}, 1852[\mathrm{M}+\mathrm{H}]^{+}$. The deprotection was achieved according to procedure $\mathrm{B}$ for obtaining 11: $60 \%$ yield. ${ }^{1} \mathrm{H}$ NMR (400 $\left.\mathrm{MHz}, \mathrm{CD}_{3} \mathrm{OD}\right) \delta$ 7.26-7.90 (m, 27H, H-np), 6.89 (d, 1H, $J=6.8 \mathrm{~Hz}, \mathrm{H}-\mathrm{np})$, $6.67\left(\mathrm{~d}, J=2.0 \mathrm{~Hz}, 1 \mathrm{H}, \mathrm{H}-1^{\prime}\right), 4.80-5.15\left(\mathrm{~m}, 4 \mathrm{H}, 2 \mathrm{CH}_{2}-\mathrm{np}\right)$, 4.65-4.80 (m, 2H, $\left.\mathrm{CH}_{2}-\mathrm{np}\right), 4.62\left(\mathrm{~m}, 1 \mathrm{H}, J=10.4 \mathrm{~Hz}, \mathrm{H}-5^{\prime}\right)$, 4.39 (m, 1H, H-4), 4.21-4.31 (m, 2H, $\left.\mathrm{CH}_{2}-\mathrm{np}\right), 4.04$ (m, 1H, H$3^{\prime}$ ), 3.85-3.93 (m, 2H, H-6, H-5), 3.40-3.70 (m, 5H, H-1, H-3, H-2', H-4', H-6'b), 3.04 (m, $\left.J=12.4 \mathrm{~Hz}, 1 \mathrm{H}, \mathrm{H}-6^{\prime} \mathrm{a}\right), 2.55$ (m, $J=12.4 \mathrm{~Hz}, 1 \mathrm{H}, \mathrm{H}-2 \mathrm{eq}), 2.11(\mathrm{~m}, J=12.4 \mathrm{~Hz}, 1 \mathrm{H}, \mathrm{H}-2 \mathrm{ax}) .{ }^{13} \mathrm{C}$ NMR (100 MHz, CD 3 OD) $\delta$ 133.0-135.1 (4C-np), 124.4128.2 (28CH-np), 92.1 (C-1'), 83.4 (C-5), 80.3 (C-6), 79.0 (C-4), 75.4 and $75.1\left(2 \mathrm{CH}_{2}-\mathrm{np}\right), 74.8\left({\mathrm{C}-5^{\prime}}^{\prime}\right), 72.8\left(\mathrm{C}-3^{\prime}\right), 72.5$ and $72.1\left(2 \mathrm{CH}_{2}-\mathrm{np}\right), 71.8\left(\mathrm{C}-4^{\prime}\right), 49.5$ and $48.9(\mathrm{C}-1, \mathrm{C}-3$ and C-2 $\left.{ }^{\prime}\right), 38.3\left(\mathrm{C}^{\prime} 6^{\prime}\right), 28.3(\mathrm{C}-2)$. LRMS $\left(\mathrm{DCI}^{+}\right) \mathrm{m} / z: 743[\mathrm{M}+\mathrm{H}]^{+}$, $603[\mathrm{M}+\mathrm{H}-2 \mathrm{NM}]^{+}, 441,303,141 . \mathrm{HRMS}_{\left(\mathrm{ESI}^{+}\right) \mathrm{m} / z:[\mathrm{M}+}+$ $\mathrm{H}]^{+}$calculated 743.3809 , found $743.3810,[\mathrm{M}+\mathrm{Na}]^{+}$calculated 765.3628 , found 765.3628 .

Antimicrobial Effects. The minimal inhibitory concentrations (MICs) were determined by a geometric microdilution method according to the recommendations of the CLSI norms for Gram negative strains (E. coli (ATCC 25922, Ec06AB003 (Arm), EcPAZ505H8101 and EcL58058.1), P. aeruginosa (ATCC 27853, PA02, PA03, PAO1, PA21, PA22, PA405, PA406 and Psa.F03), A. lwoffi (ATCC 17925 and Al.88-483), C. amalonaticus Ca06AB0010 (Arm), E. aerogenes 06AB008 (Arm)), and S. aureus strains (ATCC 33592 HA-MRSA and VRSA VRS-2). ${ }^{18}$

The method was slightly modified for $S$. aureus (ATCC 25923, S. aureus SA-1199B (harboring resistance to fluoroquinolones through overexpression of the NorA efflux pump), S.aureus MsrA (resistant to 14- and 15-membered macrolides, harboring the multicopies plasmid pUL 5054 coding for an efflux pump), S. aureus APH2" $2^{\prime \prime}$ AC6' (aminoglycoside-6'$N$-acetyltransferase $/ 2^{\prime \prime}$-O-phosphoryltransferase), S. aureus APH3' (aminoglycoside- $3^{\prime}-O$-phosphoryltransferase), and $S$. aureus ANT4' (aminoglycoside-4'- $O$-phosphoryltransferase). Briefly, the plates were incubated at $37^{\circ} \mathrm{C}$, and bacterial growth was monitored at $650 \mathrm{~nm}$ after $1,4,7$, and $24 \mathrm{~h}$ of growth. Ampicillin $(16 \mathrm{mg} / \mathrm{L})$ was used as a positive control and $2 \mu \mathrm{L}$ of DMSO as a negative control. The extract was considered as very active if there was no bacterial growth after $24 \mathrm{~h}$ incubation, as active if bacterial growth was less than $10 \%$ of the negative control and inactive if bacterial growth was more than $10 \%$ of the negative control.

Alteration of Protein Synthesis. Overnight cultures of $P$. aeruginosa ATCC 27853 were diluted in cation adjusted Muller-Hinton broth (CA-MHB) media and allowed to grow to the exponential phase (optical density at $620 \mathrm{~nm}, 0.5-0.8$ ). Cultures were then centrifuged at $4000 \mathrm{rpm}$ at $4{ }^{\circ} \mathrm{C}$ and washed two times with CA-MHB medium. Culture samples of $1.5 \mathrm{~mL}$ were incubated with $0.1,0.25,0.5,1,2.5,5$, and 10 -fold MICs of 10a, neamine 1, neomycin $\mathrm{B}$, polymyxin $\mathrm{E}$, and aztreonam at 37 ${ }^{\circ} \mathrm{C}$ during $1 \mathrm{~h}$ under shaking $(150 \mathrm{rpm})$. Samples were then centrifuged at $4000 \mathrm{rpm}$ at $4{ }^{\circ} \mathrm{C}$, washed 1 time with CA-MHB medium, and resuspended in CA-MHB medium containing $2 \mu \mathrm{Ci} / \mathrm{mL}$ of $\mathrm{L}-\left[4,5-{ }^{3} \mathrm{H}\right]$ leucine. Samples were incubated during $150 \mathrm{~min}$ at $37^{\circ} \mathrm{C}$ under shaking $(150 \mathrm{rpm})$ and then centrifuged at $4000 \mathrm{rpm}$ at $4^{\circ} \mathrm{C}$ and washed two times with ice-cold PBS buffer. An aliquot of $250 \mu \mathrm{L}$ of each sample was placed in a $20 \mathrm{~mL}$ scintillation vial with $10 \mathrm{~mL}$ of Perkin-Elmer Ultima Gold liquid scintillation cocktail and total counts were obtained in a Tri-Carb 2800TR Perkin-Elmer liquid scintillation analyzer. Another $500 \mu \mathrm{L}$ aliquot was treated with ice-cold $10 \%$ trichloroacetic acid for $10 \mathrm{~min}$ and frozen overnight. After centrifugation at $4000 \mathrm{rpm}$ at $4{ }^{\circ} \mathrm{C}, 250 \mu \mathrm{L}$ of the supernatant was analyzed to access to soluble counts. The incorporation of $\mathrm{L}-\left[4,5-{ }^{3} \mathrm{H}\right]$ leucine was obtained by the subtraction of the soluble counts to the total counts divided by the protein concentration obtained by the Lowry method. ${ }^{10}$

Isothermal Titration Calorimetry (ITC). ITC measurements were performed at $25^{\circ} \mathrm{C}$ on a MicroCal VP-ITC (MicroCal, Northampton, MA). The buffer contained $25 \mathrm{mM}$ potassium acetate, $2 \mathrm{mM}$ magnesium acetate, $20 \mathrm{mM}$ sodium cacodylate, $\mathrm{pH}$ 7.0. Forty $5 \mu \mathrm{L}$ aliquots of $200 \mu \mathrm{M}$ solution of drugs were injected into a $2 \mu \mathrm{M}$ of a model bacterial ribosomal A-site (1.42 mL sample cell). ${ }^{12}$ The duration of each injection was $10 \mathrm{~s}$, and the delay between injections was $240 \mathrm{~s}$. ITC titration curves were analyzed using the software Origin (OriginLab, Northampton, MA). A control experiment was performed with neomycin B. ${ }^{13}$

Acknowledgment. This work was supported by the French Research Agency (ANR) "Physique et Chimie du Vivant" and by the Research Department of the Communauté Française de Belgique (Concerted Research Action), the National Foundation for Scientific Research (FNRS 2.4601.06F, 3.4622.07F, 1.5.236.08.F, 3.4.597.06) and Région BruxellesCapitale which are gratefully acknowledged. We are indebted to Y. Glupczynski, P.M. Tulkens, and F. El Garch for valuable discussions and to $\mathrm{C}$. Misson and V. Mohymont for technical assistance. We thank for providing us with strains R. Vanhoof [E. coli PAZ505H8101 and L58058.1, $P$. aeruginosa ATCC 27853, Psa.F03, A. lwoffi Al.88-483], Y. Glupczynski [C. amalonaticus Ca06AB0010, E. coli 06AB003, E. aerogenes 06AB008], J.-C. Pechere [P. aeruginosa PA02, PA03], P. Plésiat [P. aeruginosa PA01, PA21, PA22], and H. Schweizer [P. aeruginosa PA405, PA406]). MRSA and VRSA strains were obtained from NARSA (Network on Antimicrobal Resistance in Staphylococcus aureus) via Eurofins Medinet, Inc., Hendon, VA).

Supporting Information Available: HPLC profiles, ${ }^{1} \mathrm{H}$ and ${ }^{13} \mathrm{C}$ NMR spectra of the neamine derivatives $6,7 \mathbf{a}$, and $10 \mathbf{a}$ active as antimicrobial agents, table of purity determined for all evaluated derivatives and ITC profiles at $25{ }^{\circ} \mathrm{C}$ for the titration of compounds 7a and 10a into a solution of a model bacterial ribosomal A site. This material is available free of charge via the Internet at http://pubs.acs.org.

\section{References}

(1) Jana, S.; Deb, J. K. Molecular understanding of aminoglycoside action and resistance. Appl. Microbiol. Biotechnol. 2006, 70, $140-150$.

(2) Borovinskaya, M. A.; Pai, R. D.; Zhang, W.; Schuwirth, B. S.; Holton, J. M.; Hirokawa, G.; Kaji, H.; Kaji, A.; Cate, J. H. D. Structural basis for aminoglycoside inhibition of bacterial ribosome recycling. Nat. Struct. Mol. Biol. 2007, 14, 727-732. Hermann, T. Aminoglycoside antibiotics: old drugs and new therapeutic approaches. Cell. Mol. Life Sci. 2007, 64, 1841-1852. Silva, J. G.; 
Carvalho, I. New insights into aminoglycoside antibiotics and derivatives. Curr. Med. Chem. 2007, 14, 1101-1119.

(3) Mingeot-Leclercq, M.-P.; Glupczynski, Y.; Tulkens, P. M. Aminoglycosides: activity and resistance. Antimicrob. Agents Chemother. 1999, 43, 727-737.

(4) Doi, Y.; Arakawa, Y. 16S Ribosomal RNA methylation: emerging resistance mechanism against aminoglycosides. Clin. Infect. Dis. 2007, 45, 88-94. Galimand, M.; Sabtcheva, S.; Courvalin, P.; Lambert, $\mathrm{T}$. Worldwide disseminated armA aminoglycoside resistance methylase gene is borne by composite transposon Tn1548. Antimicrob. Agents Chemother. 2005, 49, 2949-2953. Schmitt, E.; Galimand, M.; Panvert, M.; Courvalin, P.; Mechulam, Y. Structural bases for 16 S rRNA methylation catalyzed by ArmA and RmtB methyltransferases. J. Mol. Biol. 2009, 388, 570-582.

(5) Fourmy, D.; Recht, M. I.; Puglisi, J. D. Binding of neomycin-class aminoglycoside antibiotics to the A-site of $16 \mathrm{~S}$ rRNA. J. Mol. Biol. 1998, 277, 347-362. Francois, B.; Russell, R. J. M.; Murray, J. B; Aboulela, F.; Masquida, B.; Vicens, Q.; Westhof, E. Crystal structures of complexes between aminoglycosides and decoding A site oligonucleotides: role of the number of rings and positive charges in the specific binding leading to miscoding. Nucleic Acids Res. 2005, 33, 5677-5690.

(6) For reviews see: Kotra, L. P.; Mobashery, S. A renaissance of interest in aminoglycoside antibiotics. Curr. Org. Chem. 2001, 5, 193-205. Agnelli, F.; Sucheck, S. J.; Marby, K. A.; Rabuka, D.; Yao, S.-L.; Sears, P. S.; Liang, F.-S.; Wong, C.-H. Dimeric aminoglycosides as antibiotics. Angew. Chem., Int. Ed. 2004, 43, 1562-1566. Zhou, J.; Wang, G.; Zhang, L.-H.; Ye, X.-S. Med. Res. Rev. 2007, 27, 279-316. For example: Haddad, J.; Kotra, L. P.; Llano-Sotelo, B.; Kim, C.; Azucena, E. F.; Liu, M.; Vakuleno, S. B.; Chow, C. S.; Mobashery, S. Design of novel antibiotics that bind to the ribosomal acyltransfer site. J. Am. Chem. Soc. 2002, 124, 3229-3237.

(7) Lomadze, N.; Schneider, H.-J.; Albelda, M. T.; Garcia-Espana, E.; Verdejo, B. Dramatic selectivity differences in the association of DNA and RNA models with new ethylene- and propylene-diamine derivatives and their copper complexes. Org. Biomol. Chem. 2006, 4, 1755-1759.

(8) Riguet, E.; Désiré, J.; Bailly, C.; Décout, J.-L. A route for preparing new neamine derivatives targeting HIV-1 TAR RNA. Tetrahedron 2004, 60, 8053-8064. Riguet, E.; Désiré, J.; Boden, O.; Ludwig, V.; Göbel, M.; Bailly, C.; Décout, J.-L. Neamine dimers targeting the HIV-1 TAR RNA. Bioorg. Med. Chem. Lett. 2005, 15, 4651-4655.

(9) Zaher, M.; Baussanne, I.; Ravelet, C.; Halder, S.; Haroun, M.; Fize, J.; Décout, J.-L.; Peyrin, E. Copper(II) complexes of lipophilic aminoglycoside derivatives for the amino acid enantiomeric separation by ligand-exchange liquid chromatography. J. Chromatogr. A 2008, 1185, 291-295.

(10) Lowry, O. H.; Rosebrough, N. J.; Farr, A. L.; Randall, R. J. Protein measurement with the folin phenol reagent. J. Biol. Chem. 1951, 193, 265-275. Kirchman, D.; K'nees, E.; Hodson, R. Leucine incorporation and its potential as a measure of protein synthesis by bacteria in natural aquatic systems. Appl. Environ. Microbiol. 1985, 49, 599-607.

(11) Li, J.; Nation, R. L.; Turnidge, J. D.; Milne, R. W.; Coulthard, K.; Rayner, C. R.; Paterson, D. L. Colistin: the re-emerging antibiotic for multidrug-resistant Gram-negative bacterial infections. Lancet Infect. Dis. 2006, 6, 589-601.

(12) Kaul, M.; Barbieri, C. M.; Kerrigan, J. E.; Pilch, D. S. Coupling of drug protonation to the specific binding of aminoglycosides to the A site of $16 \mathrm{~S}$ rRNA: elucidation of the number of drug amino groups involved and their identities. J. Mol. Biol. 2003, 326, 1373-1387.

(13) Bernacchi, S.; Freisz, S.; Maechling, C.; Spiess, B.; Marquet, R.; Dumas, P.; Ennifar, E. Aminoglycoside binding to the HIV-1 RNA dimerization initiation site: thermodynamics and effect on the kissing-loop to duplex conversion. Nucleic Acids Res. 2007, 35, 7128-7139.

(14) Bera, S.; Zhanel, G. G.; Schweizer, F. Design, Synthesis, and antibacterial activities of neomycin-lipid conjugates: polycationic lipids with potent Gram-positive activity. J. Med.Chem. 2008, 51, 6160-6164.

(15) Loh, B.; Grant, C.; Hancock, R. E. W. Use of the fluorescent probe $1-N$-phenylnaphthylamine to study the interactions of aminoglycoside antibiotics with the outer membrane of Pseudomonas aeruginosa. Antimicrob. Agents Chemother. 1984, 26, 546-551. Nikaido, H.; Vaara, M. Molecular basis of bacterial outer membrane permeability. Microbiol. Rev. 1985, 49, 1-32. Nikaido, H. Molecular basis of bacterial outer membrane permeability revisited. Microbiol. Mol. Biol. Rev. 2003, 67, 593-656.

(16) Mortensen, N. P.; Fowlkes, J. D.; Sullivan, C. J.; Allison, D. P.; Larsen, N. B.; Molin, S.; Doktycz, M. J. Effects of colistin on surface ultrastructure and nanomechanics of Pseudomonas aeruginosa cells. Langmuir 2009, 25, 3728-3733.

(17) Clausell, A.; Garcia-Subirats, M.; Pujol, M.; Busquets, M. A.; Rabanal, F.; Cajal, Y. Gram-negative outer and inner membrane models: insertion of cyclic cationic lipopeptides. J.Phvs. Chem. B 2007, 111, 551-563.

(18) Ross, J. I.; Eady, E. A.; Cove, J. H.; Cundliffe, W. J.; Baumberg, S. Inducible erythromycin resistance in Staphylococci is encoded by a member of the ATP-binding transport super-gene family. Mol. Microbiol. 1990, 4, 1207-1214. Mingeot-Leclercq, M.-P.; Glupczynski, Y.; Tulkens, P. M. Aminoglycosides: activity and resistance. Antimicrob. Agents Chemother. 1999, 43, 727-737. Bush, K.; Miller, G. H. Bacterial enzymatic resistance: beta-lactamases and aminoglycoside-modifying enzymes. Curr. Opin. Microbiol. 1998, 1, 509-515. Clinical and Laboratory Standards Institute. Methods for Dilution Antimicrobial Susceptibility Test for Bacteria that Grow Aerobically; Approved Standards M7-A7 and 17th Informational Supplement M100-S17; Clinical and Laboratory Standards Institute: Wayne, PA, 2007, vol 27, no. 1 . 